$\begin{array}{ll} & \text { Preprints are preliminary reports that have not undergone peer review. } \\ \text { Research Square } & \text { They should not be considered conclusive, used to inform clinical practice, } \\ \text { or referenced by the media as validated information. }\end{array}$

\title{
Green Synthesis of Different Nanoparticles and its Effect on Irrigation Water and Soil Properties and Origanum Majorana Productivity
}

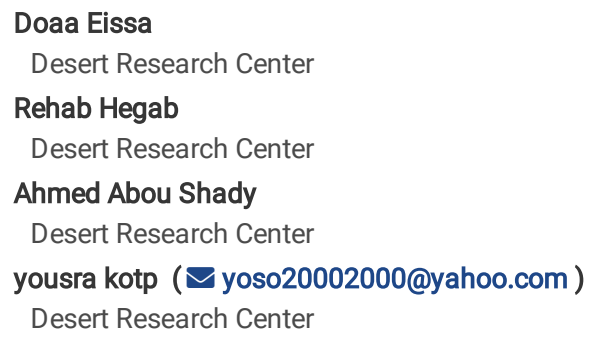

\section{Research Article}

Keywords: Nanotechnology, Agriculture, Water Treatment, Heavy Metals, Plant Productivity.

Posted Date: January 14th, 2022

DOI: https://doi.org/10.21203/rs.3.rs-1230728/v1

License: () (1) This work is licensed under a Creative Commons Attribution 4.0 International License. Read Full License 


\section{Abstract}

The term of nanotechnology has emerged recently in several fields of interest that refers to the researches and innovations that are concerned with making materials on a very small size close to the scale of atoms and molecules. In the present work, the effects of green synthesis of different nanoparticles on the quality of irrigation water, the availability of some heavy metals content in soil and the plant, and the productivity of Marjoram were studied in detail. The obtained results showed that the addition of nanoparticles (NPs) materials has resulted in noticeable variations in the removal percentages of Cu and Fe from aqueous solution. The maximum values obtained for adsorption of $\mathrm{Cu}$ (II) on $\mathrm{ZnO}, \mathrm{MgO}$, and $\mathrm{SiO}_{2} \mathrm{NPs}$, within $\mathrm{pH}(3-5)$ were $89.9 \%$, 83.3\%, and 68.36\%,

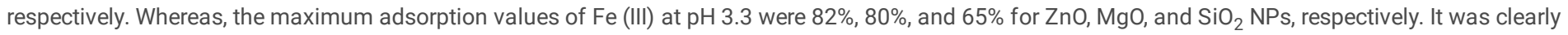
seen that the effective of NPs application on reduction of the available $\mathrm{Cu}$ in the studied soil samples. The order of sequence for the effects of NPs application was found to take the following order $\mathrm{Zn} 2>\mathrm{Zn} 1>\mathrm{Mg} 2>\mathrm{Si} 2>\mathrm{Mg} 1>\mathrm{Si} 1>\mathrm{C}$ (control). The highest values of the available Cu were observed in the control treatment, whereas the lowest values were obtained when Zn2 was added, and the same tendency was observed with the substantial concentrations of Fe. The addition of NPs to the soil samples had positively affected the Cu uptake via plant. The effects of NPs and the additions of Cu and Fe on the availability of NPK in the soil system were very completed and osculated from one treatment to another. The same tendency was observed with the total concentration of NPK in the plant.

\section{Introduction}

The term of nanotechnology has emerged recently in several fields of interest that refers to the research and improvement that is interested with making materials on a very little size close to the scale of molecules and atoms. Generally, one nanometer is calculated as one billionth of meter which is considered approximately ten times in size diameter compared to the hydrogen atom. It was informed that at nanometre sizes the chemistry and physics regulations of materials are no extended be appropriate including reactivity, strength, color, and conductivity that will substantially differ among the dimension of nano and the large-scales $[1,2]$.

In the farming division, the nanotechnology has been exploited as a potential solution for reshaping farming construction which could be carried out via replacing traditional materials that is used for farming construction like pesticides, herbicides and fertilizers, with nano-permited counterparts. Such nano scale-enabled counterparts have been informed on several agricultural practices including soil foliar applications, grain, and leafy plants [3]. Researchers are adopting green technologies for the preparation of different nanoparticles for medicinal uses in response to the increased demand for environmentally friendly nanoparticles [4]. Chemical synthesis processes such as chemical vapour deposition, micelle, sol-gel, chemical precipitation, pyrolysis, hydrothermal method, and others frequently result in the existence of poisonous chemical types adsorbed on the surface, which might have negative consequences in medical applications. Some reactions necessitate a high temperature and/or high pressure to start, while others necessitate an inert atmosphere and/or the use of toxic substances such as $\mathrm{H}_{2} \mathrm{~S}$, toxic template and stabilizer, and metallic precursors [5]. Chemicals utilized in the formation and stabilization of nanoparticles is hazardous and produce non-ecofriendly byproducts [6]. Biological processes including microbes and plants, as well as plant extracts, have been proposed as viable alternatives to chemical procedures for metal nanoparticles. Nanoparticles have been synthesised using a variety of biological systems, comprising bacteria, fungus, and yeast [7]. Microorganism-supported nanoparticle manufacturing entails a complex process involving cell culture maintenance, intracellular synthesis, and numerous purification processes. In this regard, because standard chemical procedures are costly and necessitate the utilize of chemical mix/organic solutions which act as plummeting agents, adopting "green" approaches in the manufacture of zinc oxide nanoparticles has develop into a growing area of interest [8]. There are several materials that have been utilized as fertilizer which are considered nanomaterials including nano-CaO, nano-urea, nano-hydroxiapatite (nano-HAP), Mg nanoparticles, and MgO nanoparticles. These supplies have been considered as the most widespread macronutrients reported for improving biomass construction and plant expansion. Researches that used nano-HAP and nano-Mg have reported an raising in seed yield production for Soybean (Glycine max) and Cowpea (Vigna unguiculata) [3]. The study of Liu and Lal, 2005 [9] reported an augment in the growth of Soybean vegetation (32.6\%), and yield (20.4\%) when soils were modified with nano-HAP $\left(21.8 \mathrm{mg} \mathrm{L}^{-1}\right)$, whereas when the vegetation were exposed to the same concentration of $\mathrm{Ca}\left(\mathrm{H}_{2} \mathrm{PO}_{4}\right)_{2}$ to provide the vegetation with the main source of phosphorous the obtained results were moderately small. The study presented by Aziz et al., 2016 [10] shows that the synthesized of composites with different concentrations of NPK such as 50,60 , and 400 mg kg ${ }^{-1}$ when compared to fertilizing with regular nutrients, that contained in the form of polymer (chitosan) has minimized the life cycle of nano-fertilized wheat plants. Wheat (Triticum aestivum) plants fertilized with chitosan nanoparticles containing the three major elements (NKP) via foliar application shortened the harvesting duration to 130 days after planting, compared to 170 days after planting if normal fertiliser containing NPK was used. Several scientests have described the benefits of engineered nanomaterials formulations that possessed pesticide properties [11, 12]. The study carried out by Chhipa, 2017 [12] shows that the pesticide properties that are contained silver nanoparticles within the major component have presented a noticeable influence against numerous fungi species. Whereas, when Cu NPs have been utilized, the efficiency of applications alongside bacteria and fungi has been remarkably improved. Other several materials like hezaconazole and nanosulfur have also presented high efficiency as fungicides. The only constraint of using such nanomaterials for the agricultural purpose as a pesticide is the ecological impacts that are considered not well understood yet [12]. Adisa et al., 2019 [11] studied polymersupport nanopesticides such as nanogels, nanospheres, nanofibers, and nanocapsules have classified as antimicrobials materials that possessed di卬erent environmental persistence. In general, nanospheres can store the active component that is dispersed throughout the nanomatrix, however the active ingredient is encased in the polymeric matrix [11].

The water problem has recently become a global issue, and the water reuse scenario could be one of the alternatives for reducing the strain on already available water resources [13]. The reported causes of domesticated water reprocess were establish to be osculated from one region to another (e.g. 32 percent in Asia, 51 percent in northern Europe for environmental purposes, 46 percent in California for agriculture, 7 percent in Japan for agriculture, 44 percent in Florida, 25 percent in Tunisia, 4 percent in Australia for total consumption, 25 percent in Spain for agriculture and generally 500 Mm3/year of treated wastewaters used, 75 percent in Israel for agriculture and generally $500 \mathrm{Mm} 3 /$ year of treated wastewaters used Mexico and China have also practised direct wastewater reuse without treatment [14-16]. Inorganic contaminants may accumulate in irrigation water or soils as a result of this.

Page $2 / 21$ 
The main aim of the present work is to study the effect of green synthesis of different nanoparticles on the quality of irrigation water, the availability of some heavy metals content in soil and plant, and the productivity of Marjoram.

\section{Material And Methods}

\subsection{Materials}

The materials that have been used for the green synthesis of different nanoparticles were lemon (Citruslimon) [17] peel extract meditated $\mathrm{MgO}_{\text {, }} \mathrm{SiO}_{2}$, and $\mathrm{ZnO}$ nanoparticles (NPs). The magnesium nitrate possessed high purity $\geq 98 \%$, zinc sulfate possessed high purity $\geq 98 \%$, and sodium metasilicate possessed high purity $\geq 98 \%$. All materials were purchased from Merck chemicals Ltd, whereas and fresh peels of lemons were collected from different lemons farms in Egypt. The fresh peels were first washed with distilled water and afterward soaked in ethanol $\left(\mathrm{C}_{2} \mathrm{H}_{5} \mathrm{OH}\right)$ and ammonium hydroxide solution $\left(\mathrm{NH}{ }_{4} \mathrm{OH}\right)$ that was purchased from Merck Chemicals Co., Darmstadt, Germany.

\subsubsection{Preparation of $\mathrm{MgO}, \mathrm{SiO}_{2}$, and $\mathrm{ZnO}$ NPs}

The formation of $\mathrm{MgO}, \mathrm{SiO}_{2}$, and $\mathrm{ZnO} \mathrm{NPs}$ was carried out based on two main steps including 1) the formation of lemon (Citruslimon) peel extract, 2) synthesis of $\mathrm{MgO} \mathrm{SiO}_{2}$, and $\mathrm{ZnO} \mathrm{NPs}$.

\subsubsection{Preparation of lemon peel extract}

The lemon peels (Citrus limon)were washed with distilled water several times to remove any dust that exist on the surface, afterward, the lemon peels were dried at $60^{\circ} \mathrm{C}$ inside a furnace and lasted for $48 \mathrm{~h}$. The dried lemon peels were ground, crushed, and sieved into suitable size. Extraction of the lemon peels was made with a concentration of $250 \mathrm{~g} \mathrm{~L}^{-1}$ at $25 \otimes \mathrm{C}$ for $24 \mathrm{~h}$ with steady shaking, afterward, the extract was filtered using filter paper.

\subsubsection{Synthesis of $\mathrm{MgO}, \mathrm{SiO}_{2}$, and $\mathrm{ZnO} \mathrm{NPs}$}

For preparing $\mathrm{MgO}, \mathrm{SiO}_{2}$, and $\mathrm{ZnO} \mathrm{NPs}$, we have added $0.5 \mathrm{~mol} \mathrm{~L}^{-1}$ of magnesium nitrate, sodium metasilicate, and zinc sulfate aqueous solutions to the lemon peel that has been separated previously from the extraction solution and then boiled to $70^{\square} \mathrm{C}$. Afterward, the mixture solution was boiled for $1 \mathrm{~h}$ until being reduced into a white-colored solution. This color change is considered a remarkable of formation of soluble fractions from the peel extract. It was demonstrated that the ethanol lemon peel extract contains hesperidin flavanol that discharges aglycone that may be used as a reducing agent [18, 19]The $\mathrm{pH}$ of each NPs mixture was adjusted via adding ammonium hydroxide solution $0.1 \mathrm{M} \mathrm{mol} \mathrm{L}^{-1}$ to maintain the following $\mathrm{pH}$ values $9.7,11.58$, and 6.95 for $\mathrm{MgO}$, $\mathrm{SiO}_{2}$, and $\mathrm{ZnO}$ NPs, respectively. Afterward, the precipitates were washed several times with deionized water, centrifuged, and collected in a clayey crucible and heated in a muffle at $600^{\circ} \mathrm{Cfor} 3 \mathrm{~h}$ for both $\mathrm{MgO}$, and $\mathrm{ZnO} \mathrm{NPs}$, whereas it was heated to $700^{\circ} \mathrm{C}$ for $\mathrm{SiO}_{2} \mathrm{NPs}$ formation. The elevating temperature in muffle was mandatory to vanish any organic residuals. Finally, a white precipitate for each NPs was obtained and packed carefully for further characterizations.

\subsubsection{Characterization of prepared nanoparticles}

$\mathrm{MgO}, \mathrm{SiO}_{2}$, and $\mathrm{ZnO}$ NPs were characterized using the following procedure. A powder of NPs was analyzed using X-ray diffraction spectrum (XRD) (PAN Analytical X'perttop Score plus Diffractometer) operated at $40 \mathrm{kV}$ with a current of $30 \mathrm{~mA}$ under Cu-Ka radiation of a $2 \theta$ range of $10-80^{\circ}$. The surface morphology of nanoparticles was observed with an Elevated-Resolution Transmission Electron Microscopy (JEOL JEM-1400 UHR, operated at 80 KV). The chemical structures of the prepared NPs were investigated by (FTIR) Infrared Spectra (using Nicolet Avatar 230 Spectrometer).

\subsection{Methods}

\subsubsection{Soil sampling and analysis}

The soil samples were collected from a constant depth of 0-30 cm from El-Gabal El-Asfer area, Egypt. Some soil and water properties are listed in Table 1. The soil samples were air-dried, crushed, and sieved through a 2-mm sieve to ensure the removal of gravel and organic waste. The determination of soil texture was carried out via following the International Pipette Method. The other properties of soil samples including organic matter content, $\mathrm{pH}$, and EC were carried out according to published literature [19-21]. The heavy metals content were determined using Inductively Coupled Argon Plasma Optical Emission Spectrometry (ICAP 6500 Duo, Thermo Scientific, England).N, P and K were determined in acid digested solution, which was prepared according to[22]. Available nitrogen in soil samples was extracted by $2 \mathrm{M}$ potassium chloride solution and determined according to [23]. Available potassium and phosphorous were extracted by DTPA + ammonium bicarbonate solution and measurement according to the method described by Soltanpour [24]. 
Table 1

Some physical and chemical properties of El-Gabal El-Asfer soil samples and irrigation water.

\begin{tabular}{|c|c|c|c|}
\hline Soil properties & El-Gabal El-Asfer soil & Water properties & El-Gabal El-Asfer irrigation water \\
\hline Particle size distribution (\%) & 80.30 & $\mathrm{pH}$ & 8.42 \\
\hline Sand (\%) & 7.90 & $\mathrm{EC}\left(\mathrm{dS} \mathrm{m}^{-1}\right)$ & 1.57 \\
\hline Silt (\%) & 11.80 & & \\
\hline \multicolumn{4}{|l|}{ Clay (\%) } \\
\hline \multirow[t]{6}{*}{ Texture class } & \multirow[t]{6}{*}{ Loamy sand } & Cation and anion $\left(\mathrm{mg} \mathrm{dm}^{-3}\right)$ & 3.93 \\
\hline & & $\mathrm{Ca}^{++}$ & 3.25 \\
\hline & & $\mathrm{Man}^{++}$ & 16.81 \\
\hline & & $\operatorname{IVIg}$ & 0.36 \\
\hline & & $\mathrm{Na}^{+}$ & \\
\hline & & $\mathrm{K}^{+}$ & \\
\hline $\mathrm{CaCO}_{3}(\%)$ & 9.78 & $\mathrm{HCO}_{3}^{-}$ & 8.03 \\
\hline $\mathrm{OM}(\%)$ & 2.81 & $\mathrm{CO}_{3}^{--}$ & 1.31 \\
\hline CEC (meq $100 \mathrm{~g}^{-1}$ ) & 20.70 & $\mathrm{Cl}^{-}$ & 11.41 \\
\hline $\mathrm{pH}(1: 2.5)$ & 8.01 & $\mathrm{SO}_{4}^{--}$ & 3.60 \\
\hline$E C\left(d S ~ m^{-1}\right)$ & 2.78 & & \\
\hline Total content of heavy metal $\left(\mathrm{mg} \mathrm{kg}^{-1}\right)$ & 28742 & Heavy metal $\left(\mathrm{mg} \mathrm{kg}^{-1}\right)$ & 0.04 \\
\hline $\mathrm{Fe}$ & 6.92 & $\mathrm{Fe}$ & 0.03 \\
\hline $\mathrm{Cu}$ & & $\mathrm{Cu}$ & \\
\hline Chemically extractable heavy metals $\left(\mathrm{mg} \mathrm{kg}^{-1}\right)$ & 13.24 & - & - \\
\hline $\mathrm{Fe}$ & 4.55 & - & - \\
\hline $\mathrm{Cu}$ & & & \\
\hline
\end{tabular}

\subsubsection{Adsorption experiments}

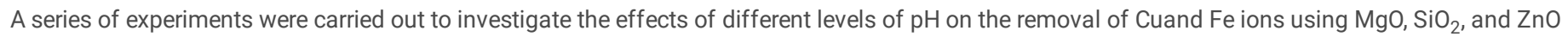
nanoparticles as adsorbent material with an initial concentration of $50 \mathrm{mg} \mathrm{L}^{-1}$ for both $\mathrm{Cu}$ and Fe. The solid to liquid ratio was $10 \mathrm{~g} \mathrm{~L}{ }^{-1}$, however, the shaking rate was $175 \mathrm{rpm}$, and finally, temperature was adjusted to $25^{\circ} \mathrm{C}$. Solutions with different $\mathrm{pH}$ values were prepared and $\mathrm{pH}$ was adjusted by adding nitric acid $0.1 \mathrm{M} \mathrm{mol}$. After the prevailing $24 \mathrm{~h}$ of adsorption, the concentrations of remaining $\mathrm{Cu}$ and Fe ions in each solution were detected via using Inductively Coupled Argon Plasma Optical Emission Spectrometry (ICAP 6500 Duo, Thermo Scientific, England).

The adsorption isotherm of $\mathrm{Cu}$ and Fe ions was carried out via using the prepared NPs as adsorbents, in which a series of concentrations of Cu and Fe were prepared via dissolving copper sulfate and iron chloride with an initial concentration of copper and iron ranging from 20 to $500 \mathrm{mg} \mathrm{L}{ }^{-1}$. The initial $\mathrm{pH}$ values for $\mathrm{Cu}$ and Fe solutions were 5.2 and 3.2, respectively. In general, $50 \mathrm{ml}$ of each solution and $0.5 \mathrm{~g}$ of adsorbent were mixed in a $100 \mathrm{ml}$ sealed conical flask that was shaken at a constant speed of $175 \mathrm{rpm}$ in a thermostatic water bath at $25^{\circ} \mathrm{C}$. After $24 \mathrm{~h}$ of adsorption, the remaining Cu and Fe concentrations in each solution were determined.

\subsubsection{Pot experiments}

Pot experiments were carried out during the cropping season 2020-2021 to investigate the effect of the MgO, $\mathrm{SiO}_{2}$, and $\mathrm{ZnO} \mathrm{NPs}_{\mathrm{s}}$ on yield and the availability of some heavy metal contents in both soil and Marjoram (Majorana Hortensis L.) [25] that was polluted with three levels from either Fe or Cu. The Marjoram (Majorana Hortensis L.) was planted in the pots containing $18 \mathrm{~kg}$ soil after approximately 30 days from seed germination. The fertilizers doses were added to all treatments (as ammonium sulphate, calcium superphosphate, potassium sulphate, and biofertilizers). The experimental design was performed in factorial design with three replicates at three levels $\left(0,5\right.$, and $\left.10 \mathrm{mg} \mathrm{kg}^{-1}\right)$ of each pollutant (Fe and $\left.\mathrm{Cu}\right)$ and $\left(0,150\right.$, and $\left.300 \mathrm{mg} \mathrm{kg}^{-1}\right)$ of each MgO, SiO 2 , and $\mathrm{ZnO}$ NPs. A sum of 35 treatments was performed after 30 and 60 days from the transplanting date (21 April and 23 May). The plants were irrigated twice a monthwith $55 \mathrm{~cm}^{3}$ of each treatment. After 97 days from the planting, the Marjoram (Majorana Hortensis L.) plants were cut at the soil surface and washed with deionized water. The plants were oven-dried at $70^{\circ} \mathrm{C}$ for $48 \mathrm{~h}$, weighed for dry matter yield, and grounded. The plants and soil samples of different treatments were digested using $\mathrm{H}_{2} \mathrm{SO}_{4}-\mathrm{H}_{2} \mathrm{O}_{2}$ according to [26]. The heavy metals content was detected via using ICAP.

\subsubsection{Statistical analysis}


Data that was obtained in the present work has been statistically analyzed and the differences between means of different treatments were considered a significant when they were more than the values of the least significant differences (LSD) at the $5 \%$ level via using Statistix program version No. 9, in which all treatments were used in a factorial design.

\section{Results And Discussion}

\subsection{Characterizations of NPs}

The XRD procedure is a widely used method for determining particle size and nanoparticle structure. The X-ray diffraction of different NPs produced with lemon peel extract is shown in Figure 1. The following is how Debye-equation Scherrer's was used to determine the dimension of $\mathrm{MgO}, \mathrm{SiO}_{2}$, and $\mathrm{ZnO} \mathrm{NPs}$

$D=K \lambda /(\beta \cos \theta)$

where $D$ is the crystal volume; $\lambda$ is the wavelength of the $X$-ray radiation $(\lambda=0.15406 \mathrm{~nm})$ for CuKa; $K$ is frequently taken as 0.9 , and $\beta$; is the line width at halfmaximum height.

Peaks of MgO NPs matching to the plane (JCPDS card No.89-7102) and found at $2 \theta=36.72^{\circ}(111), 2 \theta=42.80^{\circ}(200), 2 \theta=62.38^{\circ}(202), 2 \theta=74.5^{\circ}(311), 2 \theta$ $=78.5^{\circ}$ (312). (222). MgO NPs produced with lemon peel extract were found to be crystallized face-centered cubed (fcc) phase of magnesium oxide, according to the XRD spectrum [27]. Using Scherrer's formula, the crystal size was predicted to be around $16.77 \mathrm{~nm}$. $\mathrm{SiO}_{2} \mathrm{NPs}$ have been shown to have peaks that correspond to the planes $2 \theta=28.4^{\circ}(040), 2 \theta=31.5^{\circ}(200), 2 \theta=36.06^{\circ}(130), 2 \theta=48.4^{\circ}(330)$, and $2 \theta=56.9^{\circ}(330)$ [28]. The XRD spectrum indicates that the $\mathrm{SiO}_{2} \mathrm{NPs}$ made from lemon peels were crystalline. Using Scherrer's formula, the crystal diameters calculated were around $42.6 \mathrm{~nm}$. In addition, the patterns produced by ZnO NPs demonstrate. ZnO NP patterns also suggest that the planes were approximately $2 \theta=31.8^{\circ}(100), 2 \theta=34.4^{\circ}(100),(002) 2 \theta=36.3^{\square}$ (101), $2 \theta=47.5^{\square}(102) 2 \theta=56.6^{\square}(110), 2 \theta=56.69^{\square}(110), 2 \theta=62.8^{\square}(103), 2 \theta=67.98^{\square}(200)$, and $2 \theta=69.1^{\square}(200)$, (201). These findings are in line with those of other researchers who have shown ZnO diffractograms $[10,29]$. As indicated in Figure. 1, no contaminant diffraction peaks were identified. These findings revealed that the produced $\mathrm{ZnO}$ was extremely pure. There was no usual graphitic carbon diffraction peaks found. Because graphitic carbon is amorphous in nature, its existence cannot be ruled out. The sample's highly crystalline nature is indicated by the crisp and high diffraction peaks [30]. High heat treatment is likely to provide sufficient kinetic energy for rearranging of atomic groupings and hence the development of nanoparticle crystal structure [31]. ZnO was synthesised in this process at a sufficiently high temperature of around $500^{\circ} \mathrm{C}$, resulting in a crystalline structure product. Using Scherrer's formula, the crystallite size of the $\mathrm{ZnO}$ nanocrystallite was around $60.5 \mathrm{~nm}$.

TEM images provide a more detailed insight of the interior structure of nanoparticles. Figure 2 shows a $\mathrm{TEM}_{\mathrm{image}}$ of $\mathrm{MgO}^{\mathrm{SiO}} \mathrm{S}_{2}$, and $\mathrm{ZnO}$ nanoparticles generated by lemon peel extract. The circular structures are built of the unique individuals of distinct manufactured nanoparticles, according to the increased two-dimensional picture of the nanoparticles. Each produced nanoparticle has a size about less than $100 \mathrm{~nm}$ as measured by TEM imaging. This size corresponds to the size calculated from the XRD pattern. In order to determine the probable chemical bonds in the lemon peel extract and the produced nanoparticles, the FTIR technique was used. The FTIR spectra of $\mathrm{MgO}_{\mathrm{SiO}}$, and $\mathrm{ZnO}$ nanoparticles, as well as lemon peel extract, are shown in Fig. 3 . The spectrum of lemon peel extract had a strong peak in the area of $3200-3700 \mathrm{~cm}^{-1}$, which may be attributed to the stretching mode of the hydroxyl of phenolic, which also coincided with the $\mathrm{N}-\mathrm{H}$ of the amines, which could be attributable to the various bioactive chemicals found in lemon [32, 33]. The symmetrical and asymmetrical $\mathrm{C}-\mathrm{H}$ of the aliphatic groups has been assigned to two minor intensity peaks about $2925 \mathrm{~cm}^{-1}$. The bending vibration of the $\mathrm{OH}$ group was attributed to a wide broad peak about $1717 \mathrm{~cm}^{-1}$, which could be due to chemisorbed and/or physiosorbed moisture. on the surface of nanoparticles [34]. The occurrence of $\mathrm{C}-\mathrm{O}$ symmetric stretching of alcoholic and $\mathrm{C}-\mathrm{H}$ vibrating of the $-\mathrm{CH}=\mathrm{CH}$ of the ethylene structure can be seen in the bands at 1019 and 616 $\mathrm{cm}^{-1}$, respectively. When these peaks are compared to the spectra of MgO NPs, a decrease in peak position of MgO NPs is observed. Magnesium oxide NPs absorb at $450-850 \mathrm{~cm}^{-1}$ in the FTIR spectrum. The $0-\mathrm{H}$ stretch shows as a very broad band in the spectra, spanning $3700 \mathrm{~cm}^{-1}[35,36]$. The saturated main alcohol C=0 was found to have an absorption peak at $1092 \mathrm{~cm}^{-1}$. The substituent of flavonoids is represented by the band seen at $1456 \mathrm{~cm}^{-1}$. Our FTIR research indicates that phenolic compounds in flavonoids have a higher affinity for metal, implying that phenolic groups may produce metal nanoparticles to avoid agglomeration and therefore stabilize a media. This shows that biological molecules may have a dual role in the formation and stabilization of magnesium oxide NPs in water [34].

Glycone steroids may have played a key role in the stabilization and capping of magnesium oxide nanoparticles in our research [19, 32, 33]. When these peaks are compared to the spectra of ZnO NPs, the peak broadening of ZnO NPs is reduced. The typical Zn-O stretching vibration of ZnO NPs causes a significant peak about $450 \mathrm{~cm}^{-1}[37,38]$. Prior to the calcination of the intermediate product to $\mathrm{ZnO}$ nanoparticles, biomolecules were responsible for the conversion of $\mathrm{ZnSO}_{4}$ to $\mathrm{Zn}(\mathrm{OH})_{2}$.

Figure 3 shows the FT-IR spectra of the produced $\mathrm{SiO}_{2}$ nanoparticles. Si-O has a band around $790 \mathrm{~cm}^{-1}$, and the symmetric stretching and bending vibrations of Si-O-Si have bands around 477 and $619 \mathrm{~cm}^{-1}$ [38]. Bending vibration occurs when oxygen moves at a perfect angle to the Si-Si bands in the Si-O-Si plane $[39,40]$. The stretching vibration of the Si-O-Si band, wherein the bridging oxygen atom shifts parallel to the Si-Si lines in the reverse direction of their Si neighbors, corresponds to the band approximately $1072 \mathrm{~cm}^{-1}$. The $3555 \mathrm{~cm}^{-1}$ linked to specific to Si-OH stretching mode that are hydrogen-bonded [40].

\subsection{Batch adsorption experiments}

\subsubsection{Effect of initial pH on adsorption efficiency}

Page $5 / 21$ 
The $\mathrm{pH}$ of any solution is considered one of the most important parameters that basically influence the adsorption of ions such as $\mathrm{Cu}$ and Fe that have been studied in the present work. To evaluate the effect of $\mathrm{pH}$ on the removal efficiency of $\mathrm{Cu}$ and $\mathrm{Fe}$ a set of experiments were performed in $\mathrm{pH}$ ranging between 1 to $5 \mathrm{mg} \mathrm{kg}^{-1}$ and 1 to 3.5 , respectively. The initial concentrations of either $\mathrm{Cu}$ or Fe were close to $100 \mathrm{mg} \mathrm{L}^{-1}$ as is shown in Figure. 4 . The pH values that exceed $5 \mathrm{mg} \mathrm{kg}^{-1}$ and less than 3.5 for $\mathrm{Cu}$ and Fe ions did not study to avoid the natural phenomenon of $\mathrm{Cu}$ and Fe precipitation in hydroxide forms. It can be seen that the variations in the removal percentages with different $\mathrm{pH}$ values were approximately constant and maximum values were obtained within the $\mathrm{pH}$

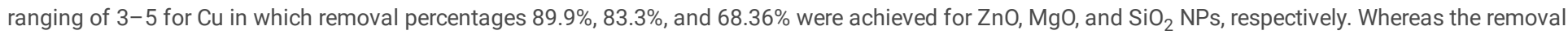

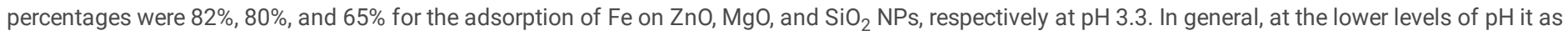
noticed the reduction in adsorption percentages. This is may be because of the reduced number of a negative sites in addition to the competition between the positive copper, iron, and hydrogen ions on these negative adsorption sites [41]. By increasing the pH of the media, more adsorptive sites can be created and the adsorption capacity will be increased. However, with continued increases in $\mathrm{pH}$ values, the formation of a precipitate of Cu and Fe hydroxide will be increased. Accordingly, it was preferable to carry out adsorption experiments at pH value of 5.2 for $\mathrm{Cu}$ and $3.3 \mathrm{for} F \mathrm{Fe}$

\subsubsection{Adsorption isotherm models}

An adsorption isotherm has been used to easily describe the adsorption of different fraction of sorbets molecules that are partitioned between liquid and solid phases at equilibrium. Generally, the adsorption of $\mathrm{Cu}$ and Fe ions on $\mathrm{ZnO}, \mathrm{MgO}$ and $\mathrm{SiO}_{2} \mathrm{NPs}$ was modeled using two adsorption isotherms as follows:

\subsubsection{Freundlich isotherm}

The Freundlich isotherm is a model that is used to represent monolayer (chemisorption) and multilayer (physisorption) adsorption, and it is founded on the supposition that the adsorbed molecules adsorbs onto the uneven surface of an adsorbent [42]. Freundlich's equation is written in linear form as follows:

$\log q_{e}=\log k_{F}+1 / n \log C_{e}$

The Freundlich isotherm coefficients $K_{F}$ and $n$ are calculated first from intercept and slope of a chart of log $q_{e}$ vs log $C_{e}$ as shown in Fig. 5. In this investigation, $\mathrm{n}$ values greater than unity were discovered, indicating chemisorptions as shown in Table 2 [43]. L-type isotherms with $\mathrm{n}>1$ suggest a high affinity between the adsorbate and the adsorbent and are suggestive of chemisorption [44]. With increasing in temperature, the Freundlich constant ( $\mathrm{K}_{\mathrm{F}}$ ), showing that, the adsorption mechanism is endothermic.

Table 2

Freundlich isotherm model parameters and correlation coefficients for the adsorption of Cu and Fe ions on $\mathrm{ZnO}, \mathrm{SiO} 2$, and $\mathrm{MgO}$ NPs.

\begin{tabular}{|c|c|c|c|c|c|c|c|c|c|c|}
\hline \multicolumn{11}{|c|}{ Freundlich isotherm model parameters } \\
\hline Metal ions & Temperature & Zno & & & $\mathrm{SiO}_{2}$ & & & MgO & & \\
\hline \multirow[t]{4}{*}{$\mathrm{Cu}^{2+}$} & & $\mathbf{n}$ & $\mathrm{K}_{\mathrm{F}}$ & $\mathrm{R}^{2}$ & $\mathbf{n}$ & $\mathrm{K}_{\mathrm{F}}$ & $\mathbf{R}^{2}$ & $\mathbf{n}$ & $\mathrm{K}_{\mathrm{F}}$ & $\mathrm{R}^{2}$ \\
\hline & 298 & 2.85 & 2.88 & 0.95 & 5.26 & 1.05 & 0.63 & 2.85 & 2.34 & 0.96 \\
\hline & 313 & 3.35 & 8.12 & 0.94 & 2.00 & 1.13 & 0.96 & 2.94 & 6.45 & 0.88 \\
\hline & 338 & 3.35 & 9.54 & 0.94 & 1.88 & 1.11 & 0.97 & 3.33 & 8.31 & 0.95 \\
\hline \multirow[t]{3}{*}{$\mathrm{Fe}^{3+}$} & 298 & 2.94 & 2.15 & 0.95 & 2.11 & 0.70 & 0.92 & 2.92 & 1.62 & 0.78 \\
\hline & 313 & 1.88 & 2.42 & 0.96 & 1.74 & 1.10 & 0.99 & 2.08 & 2.51 & 0.90 \\
\hline & 338 & 1.97 & 3.81 & 0.92 & 1.53 & 1.17 & 0.98 & 2.38 & 2.70 & 0.99 \\
\hline
\end{tabular}

\subsubsection{Langmuir isotherm}

The Langmuir isotherm assumes the adsorption of monolayer on a uniform surface with a finite number of adsorption sites. Once a site is filled, no further sorption can take place at that site. As the surface will eventually reach a saturation point where the maximum adsorption of the surface will be achieved. The linear form of the Langmuir isotherm model is described as:

$\frac{C_{\epsilon}}{q_{e}}=\frac{C_{\epsilon}}{q_{\max }}+\frac{1}{q_{\max } K_{L}}$

where $\mathrm{K}_{\mathrm{L}}$ is the Langmuir constant related to the energy of adsorption and $\mathrm{q}_{\mathrm{max}}$ is the maximum adsorption capacity (mg $\mathrm{g}^{-1}$ ) [45].The slope and intercept of plots of $\mathrm{C}_{\mathrm{e}} / \mathrm{q}_{\mathrm{e}}$ versus $\mathrm{C}_{\mathrm{e}}$, at different temperatures, were used to calculate $\mathrm{q}_{\max }$ and $\mathrm{K}_{\mathrm{L}}$ as is shown in Fig. 6 . Langmuir isotherm parameter fits for Cu and Fe adsorption on $\mathrm{ZnO}, \mathrm{MgO}$, and $\mathrm{SiO}_{2} \mathrm{NPs}$ and yielded isotherms that were in good agreement with observed behavior as presented in Table 3. The $\mathrm{Cu}$ and $\mathrm{Fe}$ adsorption capacities on $\mathrm{ZnO}, \mathrm{MgO}$, and $\mathrm{SiO}_{2} \mathrm{NPs}$ at room temperature $\left(297 \mathrm{~K}\right.$ ) were found to be 135,66 , and $58 \mathrm{mg} \mathrm{g}^{-1} \mathrm{for} \mathrm{Cu}^{2+}$ and 104,100 , and $94 \mathrm{mg} \mathrm{g}^{-1}$, 
respectively for Fe as shown in Table 3. This is much higher than the adsorption capacity of other adsorbents reported in other relevant literature in which the activated carbon reached $3.37 \mathrm{mg} \mathrm{g}^{-1}[46]$, whereas the adsorption of hematite reached $4.94 \mathrm{mg} \mathrm{g}^{-1}[47]$.

Table 3

Langmuir isotherm model parameters and correlation coefficients for the adsorption of $\mathrm{Cu}$ and $\mathrm{Fe}$ on $\mathrm{ZnO}, \mathrm{SiO} 2$, and $\mathrm{MgO}$ NPs.

\begin{tabular}{|c|c|c|c|c|c|c|c|c|c|c|}
\hline \multicolumn{11}{|c|}{ Langmuir isotherm model parameters } \\
\hline Metal ions & Temperature & Zno & & & $\mathrm{SiO}_{2}$ & & & $\mathrm{MgO}$ & & \\
\hline \multirow[t]{5}{*}{$\mathrm{Cu}$} & & $\mathrm{q}_{\max }$ & $\mathrm{K}_{\mathrm{L}}$ & $\mathbf{R}^{2}$ & $\mathrm{q}_{\max }$ & $\mathrm{K}_{\mathrm{L}}$ & $\mathbf{R}^{2}$ & $q_{\max }$ & $\mathrm{K}_{\mathrm{L}}$ & $\mathbf{R}^{2}$ \\
\hline & & $\left(\mathrm{mg} \mathrm{g}^{-1}\right)$ & $\left(\mathrm{Lmg}^{-1}\right)$ & & $\left(\mathrm{mg} \mathrm{g}^{-1}\right)$ & $\left(\mathrm{Lmg}^{-1}\right)$ & & $\left(\mathrm{mg} \mathrm{g}^{-1}\right)$ & $\left(\mathrm{Lmg}^{-1}\right)$ & \\
\hline & 298 & 135.13 & 9.54 & 0.98 & 58.82 & 2.00 & 0.94 & 66.22 & 0.01 & 0.94 \\
\hline & 313 & 370.37 & 1.61 & 0.97 & 150.57 & 9.12 & 0.94 & 305.81 & 1.38 & 0.99 \\
\hline & 338 & 403.22 & 1.42 & 0.95 & 333.33 & 6.30 & 0.92 & 370.37 & 1.51 & 0.97 \\
\hline \multirow[t]{3}{*}{$\mathrm{Fe}$} & 298 & 104.16 & 4.50 & 0.98 & 93.45 & 5.10 & 0.98 & 100.00 & 12.02 & 0.99 \\
\hline & 313 & 333.33 & 3.98 & 0.99 & 294.11 & 1.41 & 0.97 & 285.71 & 5.12 & 0.97 \\
\hline & 338 & 454.54 & 2.63 & 0.94 & 416.66 & 3.60 & 0.92 & 666.66 & 3.34 & 0.92 \\
\hline
\end{tabular}

\subsection{Effect of NPsand $\mathrm{Cu}$ and Fe additives on the availability of $\mathrm{Cu}$ and $\mathrm{Fe}$ in soil and plant}

\subsubsection{Effect of NPs and $\mathrm{Cu}$ additives on the available concentrations of $\mathrm{Cu}$ in soil and plant}

Data listed in Table 4 shows the effects of $\mathrm{Cu}$ additives with two concentrations of $5 \mathrm{mg} \mathrm{kg}^{-1}$ and $10 \mathrm{mg} \mathrm{kg}^{-1}$, respectively simultaneously with different treatments of NPs. It was clearly seen that the effect of NPs application on the availability of substantial concentrations of Cu without any pollutants additives resulted in a reduction of the available $\mathrm{Cu}$ in the studied soil samples. The order of sequence for the effects of NPs application was found to take the following order $\mathrm{Zn} 2>\mathrm{Zn} 1>\mathrm{Mg} 2>\mathrm{Si} 2>\mathrm{Mg} 1>\mathrm{Si} 1>\mathrm{C}$ (control). The highest values of the available Cu were observed in the control treatment, whereas the lowest values were obtained when Zn2 was added [48]. There was significant difference between all treatments except for the treatments of (Si2 and Mg2) and (Si1 and Mg1). When Cu was added to the soil as an external pollutant to increase the original exit values by $5 \mathrm{mg} \mathrm{kg}^{-1}$, the effects of NPs application on the availability of $\mathrm{Cu}$ that was extracted via using DTPA were took the following order Zn2 $>\mathrm{Zn} 1>\mathrm{Si} 2>\mathrm{Mg} 2>\mathrm{Si} 1>\mathrm{Mg} 1>\mathrm{C}$ (control). The highest value of the effects of adding NPs on the artificially polluted soils with $\mathrm{Cu}\left(5 \mathrm{mg} \mathrm{kg}^{-1}\right)$ was found when Zn2 was added to the soil, whereas the lowest effect was found when Mg1 was added[49]. There was a significant difference between all treatments except for the treatments of (Si2 and Mg2) and (Si1 and Mg1) similar to what was observed in control experiments. Increasing the values of original exist values of Cu by $10 \mathrm{mg} \mathrm{kg}^{-1}$ resulted in changing the order of effects of NPs to the following to take the following order $\mathrm{Zn} 2>\mathrm{Zn} 1>\mathrm{Mg} 2>\mathrm{Si} 2>\mathrm{Mg} 1>\mathrm{Si} 1>\mathrm{C}$ (control). There was a significant difference between all treatments except for the treatments of ( $\mathrm{Si} 2$ and $\mathrm{Mg} 1$ ). It was clearly seen that the highest effect of reduction on available Cu in the three trials that were studied including control, $5 \mathrm{mg} \mathrm{kg}^{-1}$, and $10 \mathrm{mg} \mathrm{kg}^{-1}$ was relevant to the additives of Zn2. The sum of values of means for each trial of NPs in the control experiment, an experiment carried out with the addition of $5 \mathrm{mg} \mathrm{kg}^{-1}$, and an experiment carried out with the addition of $10 \mathrm{mg} \mathrm{kg}{ }^{-1}$ have presented a significant differences among values except for (Si1 and Mg1).Data presented in Table 4 also explores the effects of NPs on Cu uptake via the plant that was osculated among the higher and lower values compared with the control experiments. The order of sequences for increasing Cu uptake via the plants without addition of $\mathrm{Cu}$ was found to take the following order $\mathrm{Si} 1>\mathrm{Zn} 2>\mathrm{Si} 2>\mathrm{Zn} 1>\mathrm{Mg} 1>\mathrm{C}$ (control) $>\mathrm{Mg} 2$. There was a significant difference between all treatments except for the treatments of ( $\mathrm{Si} 2$ and $\mathrm{Zn} 2)$ and ( $\mathrm{C}$ control and $\mathrm{Mg} 1)$. When $\mathrm{Cu}$ was added to the soil at constant concentrations of $5 \mathrm{mg} \mathrm{kg}{ }^{-1}$, the order of sequence of NPs application was as follows; $\mathrm{C}$ (control) $>\mathrm{Si} 1>\mathrm{Si} 2>\mathrm{Mg} 1>\mathrm{Zn} 1>\mathrm{Zn} 2>\mathrm{Mg} 2$ which indicates that the addition of NPs to the soil system had decreased Cu uptake via plant. There was a significant difference between all treatments except for the treatments of (Zn1, Si2, and Mg1). Increasing the additives of Cu pollutants to the soil by adding $10 \mathrm{mg} \mathrm{kg}^{-1}$ changed the sequence of effects of NPs to the following order C (control) $>\mathrm{Mg} 1>$ $\mathrm{Mg} 2>\mathrm{Zn} 2>\mathrm{Si} 1>\mathrm{Zn} 1>\mathrm{Si}$. There was a significant difference between all treatment except for the treatments of (Zn1, and Mg2). The application of NPs minimized the Cu levels in Marjoram because of the antagonistic impacts of metals the trend of these results agreed with those reported bySaifullah et al., [50],Hussain et al.,[51], Wang et al.,[52]. 
Table 4

Effect of NPs and Cu and Fe additives on the availability of Cu and Fe in soil and plant

\begin{tabular}{|c|c|c|c|c|c|c|c|c|}
\hline \multirow{3}{*}{ Nano Exp. } & \multicolumn{8}{|c|}{ Cu additives } \\
\hline & C & $5 \mathrm{mg} \mathrm{kg}^{-1}$ & $10 \mathrm{mg} \mathrm{kg}^{-1}$ & Mean & C & $5 \mathrm{mg} \mathrm{kg}^{-1}$ & $10 \mathrm{mg} \mathrm{kg}^{-1}$ & Mean \\
\hline & \multicolumn{4}{|l|}{ Cu-DTPA } & \multicolumn{4}{|l|}{ Cu-plant } \\
\hline C & $4.60 \mathrm{~F}$ & $5.31 \mathrm{E}$ & $9.37 \mathrm{~A}$ & $6.42 \mathrm{~A}$ & $6.89 \mathrm{~J}$ & 14.30E & 17.69B & 12.96B \\
\hline Zn1 & 1.421 & $2.45 \mathrm{H}$ & $3.40 \mathrm{G}$ & $2.42 \mathrm{E}$ & 8.591 & $13.34 \mathrm{G}$ & 8.161 & 10.03E \\
\hline $\mathrm{Zn} 2$ & $0.42 \mathrm{~J}$ & 1.661 & 1.581 & $1.22 \mathrm{~F}$ & $11.11 \mathrm{H}$ & $7.39 \mathrm{~J}$ & $14.96 \mathrm{D}$ & 11.16D \\
\hline Si1 & $3.55 \mathrm{G}$ & $4.11 \mathrm{~F}$ & 8.37B & $5.34 \mathrm{~B}$ & $35.71 \mathrm{~A}$ & $13.94 \mathrm{EF}$ & $11.44 \mathrm{H}$ & $20.36 \mathrm{~A}$ \\
\hline $\mathrm{Si} 2$ & $2.60 \mathrm{H}$ & $3.37 \mathrm{G}$ & $7.84 \mathrm{C}$ & $4.60 \mathrm{C}$ & $10.96 \mathrm{H}$ & 13.54FG & $2.49 \mathrm{M}$ & $9.00 \mathrm{~F}$ \\
\hline Mg1 & $3.36 \mathrm{G}$ & $4.53 \mathrm{~F}$ & $7.98 \mathrm{BC}$ & $5.29 \mathrm{~B}$ & $7.01 \mathrm{~J}$ & $13.48 \mathrm{FG}$ & 15.29D & $11.93 \mathrm{C}$ \\
\hline Mg2 & $2.57 \mathrm{H}$ & $3.42 \mathrm{G}$ & $6.47 \mathrm{D}$ & 4.16D & $5.31 \mathrm{~K}$ & $3.31 \mathrm{~L}$ & $16.21 \mathrm{C}$ & $8.28 \mathrm{G}$ \\
\hline Mean & $2.64 \mathrm{C}$ & 3.55B & $6.43 \mathrm{~A}$ & & $12.23 \mathrm{~A}$ & 11.33B & $12.32 \mathrm{~A}$ & \\
\hline \multirow[t]{2}{*}{ LSD at $5 \%$} & $P=0.197$ & $N=0.301$ & $P * N=0.522$ & & $P=0.220$ & $N=0.336$ & $P * N=0.582$ & \\
\hline & \multicolumn{8}{|c|}{ Fe additives } \\
\hline \multirow[t]{2}{*}{ Nano Exp. } & C & $5 \mathrm{mg} \mathrm{kg}^{-1}$ & $10 \mathrm{mg} \mathrm{kg}^{-1}$ & Mean & C & $5 \mathrm{mg} \mathrm{kg}^{-1}$ & $10 \mathrm{mg} \mathrm{kg}^{-1}$ & Mean \\
\hline & \multicolumn{4}{|l|}{ Fe-DTPA } & \multicolumn{4}{|l|}{ Fe-plant } \\
\hline C & $12.89 \mathrm{G}$ & $20.43 B$ & $29.56 \mathrm{~A}$ & $20.96 \mathrm{~A}$ & 2087.0L & $4404.8 B$ & $6277.8 A$ & $4256.5 A$ \\
\hline Zn1 & $8.61 \mathrm{~K}$ & $10.20 \mathrm{IJ}$ & $9.177 \mathrm{JK}$ & 9.33E & 1664.5Q & $1534.2 S$ & 4199.8D & $2466.2 C$ \\
\hline $\mathrm{Zn} 2$ & $5.88 \mathrm{~L}$ & $8.45 \mathrm{~K}$ & $6.75 \mathrm{~L}$ & $7.03 \mathrm{~F}$ & 1629.8R & 1779.1P & $3025.9 \mathrm{H}$ & $2144.9 \mathrm{G}$ \\
\hline Si1 & $11.93 \mathrm{GH}$ & 19.18BC & 19.18BC & 16.93B & 19698L & $3305.9 F$ & $4387.3 \mathrm{C}$ & 3221.0B \\
\hline $\mathrm{Si} 2$ & $12.88 \mathrm{G}$ & $14.62 F$ & $14.62 F$ & $15.23 \mathrm{C}$ & 2584.8J & $1315.2 \mathrm{~T}$ & $2934.8 I$ & 2278.3F \\
\hline Mg1 & $11.61 \mathrm{GH}$ & 19.86B & 19.86B & $15.88 \mathrm{C}$ & 1899.8M & 1863.90 & 3347.7E & $2370.5 E$ \\
\hline Mg2 & $10.64 \mathrm{HI}$ & 17.29DE & 17.29DE & 14.16D & $24955 \mathrm{~K}$ & $1534.8 S$ & $3164.8 \mathrm{G}$ & 2398.4D \\
\hline Mean & $10.63 \mathrm{C}$ & 16.71A & $16.71 \mathrm{~A}$ & & 2047.3C & 2248.3B & $3905.4 \mathrm{~A}$ & \\
\hline LSD at $5 \%$ & $P=0.520$ & $\mathrm{~N}=0.794$ & $P * N=1.376$ & & $P=0.8067$ & $\mathrm{~N}=1.232$ & $\mathrm{P} * \mathrm{~N}=2.134$ & \\
\hline
\end{tabular}

3.3.2 Effect of NPs and Fe additives on the available concentrations of Fe in soil and plant

The effects of Fe additives as two concentrations of $5 \mathrm{mg} \mathrm{kg}^{-1}$ and $10 \mathrm{mg} \mathrm{kg}^{-1}$ with different treatment of NPs are listed in Table 4 . It was clearly seen that the effect of NPs application on the availability of substantial concentrations of Fe without any pollutants additives resulted in the reduction of the available $\mathrm{Fe}$ in the soil samples. The order of sequence for the effects of NPs application on reduction of the available Fe was found to take the following sequence $\mathrm{Zn} 2$ $>\mathrm{Zn} 1>\mathrm{Mg} 2>\mathrm{Mg} 1>\mathrm{Si} 1>\mathrm{Si} 2>\mathrm{C}$ (control)[48]. The highest values of the available Fe were observed in the control, whereas the lowest values were obtained when $\mathrm{Zn} 2$ was added. There was a significant difference between all treatments except for the treatments of (Si1 and Mg1). When Fe was added to the soil as an external source of pollutants to increase the original exit values by $5 \mathrm{mg} \mathrm{kg}^{-1}$, the effects of NPs additions on the availability of Fe that was extracted via using DTPA were found to take the following order $\mathrm{Zn} 2>\mathrm{Zn} 1>\mathrm{Si} 2>\mathrm{Mg} 2>\mathrm{Si} 1>\mathrm{Mg} 1>\mathrm{C}$ (control) that is considered similar to what was observed with the same treatment of $\mathrm{Cu}$. The highest values of the effects of NPs addition on the artificially polluted soils with Fe $\left(5 \mathrm{mg} \mathrm{kg}^{-1}\right)$ were found when $\mathrm{Zn} 2 \mathrm{was}$ added to the soil, whereas the lowest effects were found when $\mathrm{Mg} 1$ was added. There was a significant difference between all treatments except for the treatments of $\mathrm{Mg} 1$ and control. Increasing the values of polluted Fe to $10 \mathrm{mg} \mathrm{kg}{ }^{1}$ resulted in changing the order of effects of NPs to the following order Zn2 > Zn1 > Si2 > $\mathrm{Mg} 2>\mathrm{Si} 1>\mathrm{Mg} 1>\mathrm{C}$ (control). There was a significant difference between all treatments. It was clearly seen that the highest effect in the three trials that were studied in the present work including control, $5 \mathrm{mg} \mathrm{kg}^{-1}$, and $10 \mathrm{mg} \mathrm{kg}^{-1}$ was relevant to the additives of Zn2[49, 53]. Data presented in Table 4 also explores the effects of NPs on Fe uptake via the plants that were osculated among the higher and lower values compared with the control experiments. The order of sequences of NPs for increasing Fe uptake via the plants was found to take the following order Si2 $>$ Mg2 $>$ C (control) $>$ Si1 $>$ Mg2 $>$ Zn1 $>$ Zn2. There was a significant difference between all treatments except for the treatments of (control and Si1). When Fe was added to the soil at constant concentrations of $5 \mathrm{mg}$ $\mathrm{kg}^{-1}$, the order of sequence of NPs application was as follows; C (control) $>\mathrm{Si} 1>\mathrm{Mg} 1>\mathrm{Zn} 2>\mathrm{Mg} 2>\mathrm{Zn} 1>\mathrm{Si} 2$ that indicates that the addition of NPs to the soil system had positive effects of the Cu uptake via the plant. There was a significant difference between all treatments except for the treatments of (Mg2 and $\mathrm{Zn} 1$ ). Increasing the additives of Fe pollutants to the soil via adding $10 \mathrm{mg} \mathrm{kg}^{-1}$ changed the sequence of effects of NPs on increasing Fe concentrations inside the plant tissue to the following order $\mathrm{C}$ (control) $>\mathrm{Si} 1>\mathrm{Zn} 1>\mathrm{Mg} 1>\mathrm{Mg} 2>\mathrm{Zn} 2>\mathrm{Si}[49,53]$. There was a significant difference between all treatments. At the root surface, NPs can compete with Fe as both the metals are being transported by common transporters in the roots [54]. The higher Zn concentrations in the roots may inhibit the Fe uptake by Marjoram plants. The trend of these results agreed with those reported by Ali et al., [55] who suggested that the improved Zn nutritional status with the foliar applied ZnO NPs may suppress the expression of Zn transporters in roots, decreasing the Cd

Page 8/21 
accumulation by roots. This variation in metal accumulation by plants under NP treatments might be due to variation in size and shape of NPs as well as crop species and mode of application of NPs.

\section{Effect of $\mathrm{Cu}$, Fe additives and NPs treatment on the availability and accumulation of N, P, and K in the treated soils and plants}

\subsubsection{Effect of Cu additives and NPs treatment on the availability of N, P, and K in soils}

The effects of Cu additives with two concentrations of $5 \mathrm{mg} \mathrm{kg}^{-1}$ and $10 \mathrm{mg} \mathrm{kg}^{-1}$ simultaneously with different treatment of NPs are listed in Table 5 . It was clearly seen that the effects of NPs application on the availability of substantial concentrations of N without any pollutants additives resulted in an osculating in the reduction or increment of the available $\mathrm{N}$ in the soil system. The order of sequence for the effects of NPs application on reducing available $\mathrm{N}$ was found to take the following sequence $\mathrm{Mg} 2>\mathrm{Mg} 1>\mathrm{C}$ (control) $>\mathrm{Si} 2>\mathrm{Zn} 2>\mathrm{Zn} 1>\mathrm{Si}$. The highest values that were affected the reduction of the available $\mathrm{N}$ were observed with $\mathrm{Mg}$ 2, whereas the lowest values were obtained when Si1 was added. There was a significant difference between all treatments except for the treatments of (control and Mg1) [49,53]. When Cu was added to the soil as an external pollutant to increase the original exit values by $5 \mathrm{mg} \mathrm{kg}^{-1}$, the effects of NPs application on the availability of $\mathrm{N}$ were found to take the following order Mg2 $>\mathrm{Zn} 2>\mathrm{Si} 2>\mathrm{Si} 1>\mathrm{Mg} 2>\mathrm{Si} 2>\mathrm{C}$ (control) $>\mathrm{Zn} 1$. The highest value of the effects of adding NPs on the artificially polluted soils with $\mathrm{Cu}\left(5 \mathrm{mg} \mathrm{kg}^{-1}\right)$ to reduce the availability of $\mathrm{N}$ was found when Mg2 was added to the soil, whereas the lowest effect was found when $\mathrm{Zn} 1$ was added. There was a significant difference between all treatments except for the treatments of (control and $\mathrm{Si}$ ) and (Z2 and Si1). Increasing the values of polluted Cu to $10 \mathrm{mg} \mathrm{kg}^{-1}$ resulted in changing the order of effects of NPs on the availability of $\mathrm{N}$ to the following order $\mathrm{Si} 2>\mathrm{Mg} 1=\mathrm{Mg} 2=\mathrm{Si} 1=\mathrm{Zn} 2>\mathrm{C}$ (control) $>\mathrm{Zn} 1$. There was a significant difference between all treatments except for the following treatments $\mathrm{Mg} 1, \mathrm{Mg} 2, \mathrm{Si1}$, and $\mathrm{Zn} 2$. It was clearly seen that the highest effects in the three trials that were studied in the present work including control, $5 \mathrm{mg} \mathrm{kg}^{-1}$, and 10 $\mathrm{mg} \mathrm{kg}^{-1}$ were osculated among Mg2 and Si2. The effects of Cu additives as two concentrations of $5 \mathrm{mg} \mathrm{kg}^{-1}$ and $10 \mathrm{mg} \mathrm{kg}^{-1}$ simultaneously with different treatment of NPs on available phosphorous (P) are listed in Table 5. It was clearly seen that the effect of NPs application on the availability of substantial concentrations of $\mathrm{P}$ without any pollutants additives resulted in an osculating of the reduction or increment of the available $\mathrm{P}$ in the soil system. The order of sequence for the effects of NPs application on reducing available $\mathrm{P}$ was found to take the following sequence $\mathrm{Zn2}>\mathrm{C}(\mathrm{control})>\mathrm{Mg} 2>\mathrm{Mg} 1>\mathrm{Zn} 1>\mathrm{Si} 1>$ $\mathrm{Si}$. The highest values that affected the reduction of the available P were observed with Zn2, whereas the lowest values were obtained when Si2 was added. There was a significant difference between all treatments except for the treatments of (control and Zn2). When Cu was added to the soil as an external pollutant to increase the original exit values by $5 \mathrm{mg} \mathrm{kg}^{-1}$, the effects of NPs application on reducing the availability of $\mathrm{P}$ was found to take the following order $\mathrm{Mg} 2>\mathrm{Si} 2>\mathrm{Mg} 1>\mathrm{Zn} 1>\mathrm{C}($ control $)>\mathrm{Si} 1>\mathrm{Zn} 2,[49,53]$. The highest value of the effects of adding NPs on the artificially polluted soils with Cu (5 mg kg $\left.{ }^{-1}\right)$ to reduce the availability of $\mathrm{P}$ was found when $\mathrm{Mg} 2$ was added to the soil, whereas the lowest effect was found when $\mathrm{Zn} 2$ was added. There was a significant

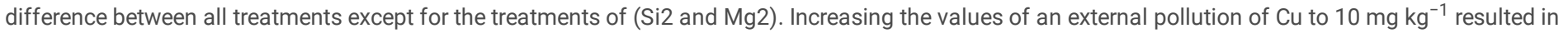
changing the order of effects of NPs on the availability of $\mathrm{P}$ to the following order $\mathrm{C}$ (control) $>\mathrm{Zn} 1>\mathrm{Mg} 2>\mathrm{Si} 1=\mathrm{Si} 2>\mathrm{Mg} 1>\mathrm{Zn} 2$. There was a significant difference between all treatments except for the following treatments ( $\mathrm{Si} 1$ and Si2). It was clearly seen that the highest effects in the three trials that were studied in the present work including control, $5 \mathrm{mg} \mathrm{kg}^{-1}$, and $10 \mathrm{mg} \mathrm{kg}^{-1}$ were osculated among Zn2, Mg2, and control. The effects of Cu additives with two concentrations of $5 \mathrm{mg} \mathrm{kg}^{-1}$ and $10 \mathrm{mg} \mathrm{kg}^{-1}$ simultaneously with different treatment of NPs on the availability of $\mathrm{K}$ are also listed in Table 5 . It was clearly seen that the effect of NPs application on the availability of substantial concentrations of $\mathrm{K}$ without any pollutants additives resulted in an osculation in the reduction or increment of the available concentrations of available K in the soil system. The order of sequence for the effects of NPs application on reducing the available concentrations of $\mathrm{K}$ was found to take the following sequence Mg2 > Si2 >Mg1 > C (control) $>$ Si1 $>$ Zn1 $>$ Zn2. The highest values affected the reduction of the available $\mathrm{K}$ were observed with $\mathrm{Mg} 2$, whereas the lowest value was obtained when $\mathrm{Zn} 2$ was added. There was a significant difference between all treatments except for the treatments of ( $\mathrm{Si} 2$ and $\mathrm{Mg} 1$ ). When $\mathrm{Cu}$ was added to the soil as an external pollutant to increase the original exit values by $5 \mathrm{mg} \mathrm{kg}^{-1}$, the effects of NPs application on the availability of $\mathrm{K}$ were found to take the following order Si1 $>$ Mg1 $>\mathrm{Zn} 2>\mathrm{C}$ (control) $>\mathrm{Mg} 2>\mathrm{Zn} 1>\mathrm{Si} 2$. The highest value of the effect of adding NPs on the artificially polluted soils with $\mathrm{Cu}\left(5 \mathrm{mg} \mathrm{kg}^{-1}\right)$ to reduce the availability of K was found when Si1 was added to the soil, whereas the lowest effect was found when Si2 was added. Generally, there was a significant difference between all treatments. Increasing the values of an external polluted Cu to $10 \mathrm{mg} \mathrm{kg}^{-1}$ resulted in changing the order of effects of NPs on the availability of $\mathrm{K}$ to the following order Si2 > Si1 > $\mathrm{Mg} 2>\mathrm{Zn} 2>\mathrm{Mg} 1=\mathrm{Zn} 1>\mathrm{C}$ (control). There was a significant difference between all treatments. It was clearly seen that the highest effects in the three trials that were studied in the present work including control, $5 \mathrm{mg} \mathrm{kg}^{-1}$, and $10 \mathrm{mg} \mathrm{kg}^{-1}$ on K availability were osculated among Mg2, Si1, and Si2. On the other hand, the lowest effects were attributed to the $\mathrm{Zn} 2$ in the control experiment, whereas in the experiments that have been carried out with the addition of $\mathrm{Cu}(5$ $\mathrm{mg} \mathrm{kg}^{-1}$ and $10 \mathrm{mg} \mathrm{kg}^{-1}$ ), the effects of Si2 and control were more dominant. The highest values of available $\mathrm{K}$ were found with the control experiment followed by the experiments that were carried out with the addition of an external Cu with concentrations of $5 \mathrm{mg} \mathrm{kg}^{-1} \mathrm{and} 10 \mathrm{mg} \mathrm{kg}^{-1}$, respectively. 
Table 5

Effect of $\mathrm{Cu}$ and Fe additives and NPs treatment on the availability and accumulation of N, P, and K in the treated soils

\begin{tabular}{|c|c|c|c|c|c|c|c|c|c|c|c|}
\hline \multirow{3}{*}{$\begin{array}{l}\text { Nano } \\
\text { Exp. }\end{array}$} & \multicolumn{11}{|c|}{ Cu additives } \\
\hline & C & $\begin{array}{l}5 \mathrm{mg} \\
\mathrm{kg}^{-1}\end{array}$ & $10 \mathrm{mg} \mathrm{kg}^{-1}$ & Mean & C & $\begin{array}{l}5 \mathrm{mg} \\
\mathrm{kg}^{-1}\end{array}$ & $10 \mathrm{mg} \mathrm{kg}^{-1}$ & Mean & C & $\begin{array}{l}5 \mathrm{mg} \\
\mathrm{kg}^{-1}\end{array}$ & $10 \mathrm{mg} \mathrm{kg}^{-1}$ \\
\hline & \multicolumn{4}{|l|}{$\mathrm{N}$} & \multicolumn{4}{|l|}{$P$} & \multicolumn{3}{|l|}{$\mathrm{K}$} \\
\hline C & $50.73 \mathrm{G}$ & $121.80 \mathrm{C}$ & $84.60 \mathrm{E}$ & 85.71D & $25.11 \mathrm{G}$ & $29.00 \mathrm{D}$ & $15.52 \mathrm{~J}$ & 23.21D & $140.80 \mathrm{~F}$ & 133.74F & 178.90D \\
\hline Zn1 & 135.33B & 135.33B & 135.33B & $135.33 \mathrm{~A}$ & $28.85 \mathrm{D}$ & $22.23 \mathrm{H}$ & 17.061 & 22.72D & $188.27 \mathrm{C}$ & $209.32 B$ & $119.60 \mathrm{G}$ \\
\hline Zn2 & $118.40 \mathrm{C}$ & $84.60 \mathrm{E}$ & $67.67 \mathrm{~F}$ & $90.22 \mathrm{C}$ & $24.78 \mathrm{G}$ & $32.56 \mathrm{AB}$ & $32.29 A B$ & $29.88 \mathrm{~A}$ & $203.20 B$ & $107.91 \mathrm{IJ}$ & $116.30 \mathrm{GH}$ \\
\hline Si1 & $203.00 \mathrm{~A}$ & 88.00E & $67.67 \mathrm{~F}$ & 119.56B & $31.61 \mathrm{BC}$ & $30.81 \mathrm{C}$ & 26.74E & $29.72 \mathrm{~A}$ & $149.80 \mathrm{E}$ & $87.82 \mathrm{~K}$ & $58.90 \mathrm{~L}$ \\
\hline $\mathrm{Si} 2$ & $88.00 \mathrm{E}$ & $118.40 \mathrm{C}$ & $50.73 \mathrm{G}$ & 85.71D & $33.09 \mathrm{~A}$ & $14.10 \mathrm{~K}$ & $26.74 \mathrm{E}$ & 24.64B & $114.03 \mathrm{GHI}$ & $221.75 \mathrm{~A}$ & $40.97 \mathrm{M}$ \\
\hline Mg1 & $50.73 \mathrm{G}$ & $50.73 \mathrm{G}$ & $67.67 \mathrm{~F}$ & 56.38E & 26.47EF & $16.26 \mathrm{IJ}$ & 28.97D & $23.90 \mathrm{C}$ & $115.17 \mathrm{GHI}$ & $102.75 \mathrm{~J}$ & $119.60 \mathrm{G}$ \\
\hline Mg2 & $10.53 \mathrm{D}$ & 101.53D & $67.67 \mathrm{~F}$ & $90.24 \mathrm{C}$ & $25.64 \mathrm{FG}$ & $13.71 \mathrm{~K}$ & $26.50 \mathrm{EF}$ & 21.95E & 109.07HIJ & $155.74 \mathrm{E}$ & 109.63HIJ \\
\hline Mean & $106.82 \mathrm{~A}$ & $100.06 \mathrm{~B}$ & $77.33 \mathrm{C}$ & & 27.93B & $22.67 C$ & 24.83B & & $145.76 \mathrm{~A}$ & $145.58 \mathrm{~A}$ & 106.27B \\
\hline \multirow{2}{*}{$\begin{array}{l}\text { LSD } \\
\text { at } 5 \%\end{array}$} & $P=2.5823$ & $\mathrm{~N}=3.9446$ & $P * N=6.8322$ & & $P=0.3989$ & $\mathrm{~N}=0.6093$ & $P * N=1.0554$ & & $P=3.1479$ & $\mathrm{~N}=4.8085$ & $P * N=8.3287$ \\
\hline & \multicolumn{11}{|c|}{ Fe additives } \\
\hline \multirow[t]{2}{*}{$\begin{array}{l}\text { Nano } \\
\text { Exp. }\end{array}$} & C & $\begin{array}{l}5 \mathrm{mg} \\
\mathrm{kg}^{-1}\end{array}$ & $10 \mathrm{mg} \mathrm{kg}^{-1}$ & Mean & C & $\begin{array}{l}5 \mathrm{mg} \\
\mathrm{kg}^{-1}\end{array}$ & $10 \mathrm{mg} \mathrm{kg}^{-1}$ & Mean & C & $\begin{array}{l}5 \mathrm{mg} \\
\mathrm{kg}^{-1}\end{array}$ & $10 \mathrm{mg} \mathrm{kg}^{-1}$ \\
\hline & \multicolumn{4}{|l|}{$\mathrm{N}$} & \multicolumn{4}{|l|}{$\mathrm{P}$} & \multicolumn{3}{|l|}{$\mathrm{K}$} \\
\hline C & $50.73 \mathrm{G}$ & 101.50D & 84.60E & 78.94E & $25.11 \mathrm{~F}$ & $29.09 \mathrm{C}$ & $18.08 \mathrm{G}$ & $24.09 \mathrm{~A}$ & $140.80 \mathrm{IJ}$ & $145.60 \mathrm{HI}$ & $150.37 \mathrm{GH}$ \\
\hline Zn1 & 135.33B & $118.40 \mathrm{C}$ & $67.67 \mathrm{~F}$ & $107.13 \mathrm{C}$ & $28.85 \mathrm{C}$ & $26.94 \mathrm{D}$ & $16.38 \mathrm{H}$ & $24.06 \mathrm{~A}$ & 188.27D & 179.09E & 197.83BC \\
\hline $\mathrm{Zn} 2$ & $118.40 \mathrm{C}$ & $67.67 \mathrm{~F}$ & $84.58 \mathrm{E}$ & $90.22 \mathrm{D}$ & $24.78 \mathrm{~F}$ & $15.49 \mathrm{H}$ & $16.32 \mathrm{H}$ & $18.86 \mathrm{C}$ & $203.20 A B$ & $135.27 \mathrm{~J}$ & $168.57 \mathrm{~F}$ \\
\hline Si1 & $203.00 \mathrm{~A}$ & 101.53D & $50.73 G$ & $118.42 \mathrm{~A}$ & 31.61B & 13.71JK & 8.87L & 18.06D & $149.80 \mathrm{H}$ & 201.67B & $207.60 \mathrm{~A}$ \\
\hline $\mathrm{Si} 2$ & $88.00 \mathrm{E}$ & $84.60 \mathrm{E}$ & $67.67 \mathrm{~F}$ & $80.09 E$ & $33.09 \mathrm{~A}$ & $15.28 \mathrm{HI}$ & $16.23 \mathrm{H}$ & 21.53B & $114.03 \mathrm{KL}$ & $140.23 \mathrm{IJ}$ & 199.94B \\
\hline Mg1 & $50.73 \mathrm{G}$ & 101.53D & $84.60 \mathrm{E}$ & 78.96E & 26.47DE & $14.19 \mathrm{IJ}$ & $12.61 \mathrm{~K}$ & 17.76D & $115.17 \mathrm{~K}$ & 194.03C & 198.22BC \\
\hline Mg2 & 101.53D & 101.50D & 135.33B & $112.79 \mathrm{~B}$ & $25.64 \mathrm{EF}$ & $13.62 \mathrm{JK}$ & $16.08 \mathrm{H}$ & $18.45 \mathrm{CD}$ & 109.07L & $155.93 \mathrm{G}$ & 173.70EF \\
\hline Mean & $106.82 \mathrm{~A}$ & 96.68B & $82.17 \mathrm{C}$ & & $27.93 \mathrm{~A}$ & 18.33B & $14.94 \mathrm{C}$ & & $145.76 \mathrm{C}$ & 164.55B & $185.18 A$ \\
\hline $\begin{array}{l}\text { LSD } \\
\text { at } 5 \%\end{array}$ & $P=2.3657$ & $N=3.6137$ & $P * N=6.2591$ & & $P=0.4541$ & $N=0.6937$ & $P * N=1.2014$ & & $P=2.1487$ & $\mathrm{~N}=3.2822$ & $P * N=5.6849$ \\
\hline
\end{tabular}

\subsubsection{Effect of Fe additives and NPs treatment on the availability of N, P, and K in the treated soils}

The effects of Fe additives with two concentrations of $5 \mathrm{mg} \mathrm{kg}^{-1}$ and $10 \mathrm{mg} \mathrm{kg}^{-1}$ simultaneously with different treatment of NPs are listed in Table 6 . It was clearly seen that the effect of NPs application on the availability of substantial concentrations of $\mathrm{N}$ without any an external Fe additives resulted in an osculating in the reduction or increment of the available $\mathrm{N}$ in the soil system. The order of sequence for the effects of NPs application on reducing the available $\mathrm{N}$ was found to take the following sequence $\mathrm{C}$ (control) $=\mathrm{Mg} 1>\mathrm{Si} 1>\mathrm{Mg} 2>\mathrm{Zn} 2>\mathrm{Zn} 1>\mathrm{Si}$. The highest values that affected the reduction of the available $\mathrm{N}$ were observed with both control and $\mathrm{Mg} 1$, whereas the lowest values were obtained when Si1 was added. There was a significant difference between all treatments except for the treatments of (control and $\mathrm{Mg} 1$ ). When Fe was added to the soil as an external pollutant to increase the original exit values by $5 \mathrm{mg} \mathrm{kg}^{-1}$, the effects of NPs application on the reduction of available $\mathrm{N}$ were found to take the following order $\mathrm{Zn} 2>\mathrm{Si} 2>\mathrm{Mg} 2=\mathrm{C}$ (control) $>\mathrm{Si} 1=$ $\mathrm{Mg} 1>\mathrm{Zn} 1$. The highest value of the effects of adding NPs on the artificially polluted soils with $\mathrm{Fe}\left(5 \mathrm{mg} \mathrm{kg}^{-1}\right)$ to reduce the availability of $\mathrm{N}$ was found when $\mathrm{Zn} 2$ was added to the soil, whereas the lowest effect was found when Zn1 was added. There was a significant difference between all treatments except for

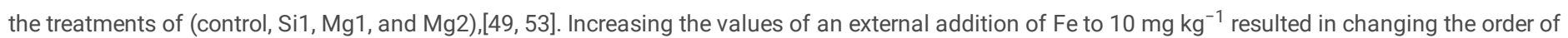
effects of NPs on reducing the availability of $\mathrm{N}$ to the following order Si1 $>\mathrm{Zn} 1=\mathrm{Si} 2=\mathrm{Zn} 2>\mathrm{C}$ (control) $>\mathrm{Mg} 1>\mathrm{Mg} 2$. There was a significant difference between all treatments except for the following treatments (control and Zn2), (Zn2 and Mg1), and (Zn1 and Si12). It was clearly seen that the highest effect in the three trials that were studied in the present work including control, $5 \mathrm{mg} \mathrm{kg}^{-1}$, and $10 \mathrm{mg} \mathrm{kg}^{-1}$ was osculated among Mg1, control, Zn2, and Si1. On the other hand, the lowest effects were attributed to the Si1 in the control experiment, whereas in the experiments that have been carried out with the addition of Fe with concentrations of $5 \mathrm{mg} \mathrm{kg}^{-1} 10 \mathrm{mg} \mathrm{kg}^{-1}$, the effects of $\mathrm{Zn} 1$ and $\mathrm{Mg} 2$ were more dominant. The highest values of available $\mathrm{N}$ were found with the control experiment followed by experiments that were carried out with the addition of Fe at concentrations of $5 \mathrm{mg} \mathrm{kg}^{-1} \mathrm{and}_{10} \mathrm{mg} \mathrm{kg}^{-1}$. The effects of Fe additives with two concentrations of $5 \mathrm{mg} \mathrm{kg}^{-1}$ and $10 \mathrm{mg} \mathrm{kg}^{-1}$ with different treatment of NPs on the reduction of available P are listed in Table 6 . It was clearly seen that the effect of NPs application on the availability of substantial concentrations of P in soil without any pollutants additives resulted in an osculating in the reduction or increment values of the available P in the soil system. The order of sequence for the effects of NPs application on reducing the 
available $\mathrm{P}$ was found to take the following sequence $\mathrm{Zn} 2>\mathrm{C}$ (control) $>\mathrm{Mg} 2>\mathrm{Mg} 1>\mathrm{Zn} 1>\mathrm{Si} 1>\mathrm{Si} 2$. The highest values affected the reduction of the available $\mathrm{P}$ were observed with $\mathrm{Zn} 2$, whereas the lowest values were obtained when Si2 was added. There was a significant difference between all treatments [53]. When Fe was added to the soil as an external pollutant to increase the original exit values by $5 \mathrm{mg} \mathrm{kg}^{-1}$, the effects of NPs application on the availability of $\mathrm{P}$ were found to take the following order Mg2 $>\mathrm{Si} 2>\mathrm{Mg} 1>\mathrm{Si} 2>\mathrm{Zn} 2>\mathrm{Zn} 1>\mathrm{C}$ (control). The highest value of the effects of adding NPs on the artificially polluted soils with Fe (5 mg kg$\left.{ }^{-1}\right)$ to reduce the availability of $\mathrm{P}$ was found when Mg2 was added to the soil, whereas the lowest effect was found when Zn1 was added. There was a significant difference between all treatments except for the treatments of (Si1 and Mg2). Increasing the values of an external addition of Fe to $10 \mathrm{mg} \mathrm{kg}^{-1}$ resulted in changing the order of effects of NPs on the availability of $\mathrm{P}$ to the following order Si1 $>\mathrm{Mg} 1>\mathrm{Mg} 2>\mathrm{Si} 2>\mathrm{Zn} 2>\mathrm{Zn} 1>\mathrm{C}$ (control). There was a significant difference between all treatments except for the following treatments (Zn1, Zn2, Si2, and Mg2).

Table 6

Effect of $\mathrm{Cu}$ and Fe additives and NPs treatment on the availability and accumulation of N, P, and K in plant.

\begin{tabular}{|c|c|c|c|c|c|c|c|c|c|c|c|}
\hline \multirow{3}{*}{$\begin{array}{l}\text { Nano } \\
\text { Exp. }\end{array}$} & \multicolumn{11}{|c|}{ Cu additives } \\
\hline & C & $\begin{array}{l}5 \mathrm{mg} \\
\mathrm{kg}^{-1}\end{array}$ & $10 \mathrm{mg} \mathrm{kg}^{-1}$ & Mean & C & $\begin{array}{l}5 \mathrm{mg} \\
\mathrm{kg}^{-1}\end{array}$ & $10 \mathrm{mg} \mathrm{kg}^{-1}$ & Mean & C & $\begin{array}{l}5 \mathrm{mg} \\
\mathrm{kg}^{-1}\end{array}$ & $10 \mathrm{mg} \mathrm{kg}^{-1}$ \\
\hline & \multicolumn{4}{|l|}{$\mathbf{N}$} & \multicolumn{4}{|l|}{$\mathbf{P}$} & \multicolumn{3}{|l|}{$\mathbf{K}$} \\
\hline C & 2.783E & $3.750 \mathrm{C}$ & $3.750 \mathrm{C}$ & $3.428 \mathrm{~B}$ & $0.236 \mathrm{DE}$ & $0.213 \mathrm{GH}$ & $0.155 \mathrm{~K}$ & $0.201 \mathrm{D}$ & 1.003EF & $0.903 \mathrm{HI}$ & $1.100 \mathrm{D}$ \\
\hline Zn1 & $1.453 \mathrm{G}$ & $2.900 \mathrm{E}$ & $3.146 \mathrm{D}$ & $2.500 \mathrm{G}$ & $0.227 \mathrm{EF}$ & $0.250 \mathrm{~B}$ & $0.178 \mathrm{~J}$ & $0.218 \mathrm{~B}$ & $0.320 \mathrm{~L}$ & $1.377 \mathrm{C}$ & 1.077 D \\
\hline $\mathrm{Zn} 2$ & $3.266 \mathrm{D}$ & $2.783 \mathrm{E}$ & $3.266 \mathrm{D}$ & $3.106 \mathrm{C}$ & $0.215 \mathrm{GH}$ & $0.196 I$ & $0.065 \mathrm{P}$ & $0.159 \mathrm{~F}$ & $1.673 \mathrm{~B}$ & $1.367 \mathrm{C}$ & $0.983 \mathrm{EFG}$ \\
\hline Si1 & $2.056 \mathrm{~F}$ & $2.173 F$ & $3.866 \mathrm{BC}$ & $2.699 \mathrm{~F}$ & $0.271 \mathrm{~A}$ & $0.206 \mathrm{H}$ & $0.220 \mathrm{FG}$ & $0.238 A$ & $0.817 \mathrm{~J}$ & $1.043 \mathrm{DE}$ & $0.907 \mathrm{HI}$ \\
\hline $\mathrm{Si} 2$ & $2.880 \mathrm{E}$ & $3.866 \mathrm{BC}$ & $4.233 \mathrm{~A}$ & $3.660 \mathrm{~A}$ & $0.246 \mathrm{BC}$ & $0.240 \mathrm{CD}$ & $0.134 \mathrm{MN}$ & $0.206 \mathrm{C}$ & $0.850 \mathrm{IJ}$ & $1.8500 \mathrm{~A}$ & $0.970 F G$ \\
\hline Mg1 & $2.173 \mathrm{~F}$ & $3.146 \mathrm{D}$ & $3.266 \mathrm{D}$ & $2.862 E$ & $0.245 B C$ & $0.140 \mathrm{LM}$ & $0.127 \mathrm{~N}$ & $0.171 E$ & $\begin{array}{l}0.990 \\
\text { EFG }\end{array}$ & $0.827 \mathrm{~J}$ & $0.950 \mathrm{FGH}$ \\
\hline Mg2 & 3.993B & $2.900 \mathrm{E}$ & $2.173 \mathrm{~F}$ & $3.022 \mathrm{D}$ & $0.142 \mathrm{LM}$ & $0.143 \mathrm{~L}$ & 0.1130 & $0.133 G$ & $0.937 \mathrm{GH}$ & $1.070 \mathrm{D}$ & $0.743 \mathrm{~K}$ \\
\hline Mean & $2.658 \mathrm{C}$ & $3.074 \mathrm{~B}$ & $3.386 \mathrm{~A}$ & & $0.226 \mathrm{~A}$ & $0.198 B$ & $0.142 \mathrm{C}$ & & $0.941 B$ & $1.205 \mathrm{~A}$ & $0.961 \mathrm{~B}$ \\
\hline $\begin{array}{l}\text { LSD } \\
\text { at } 5 \%\end{array}$ & $P=0.0496$ & $\mathrm{~N}=0.0758$ & $P * N=0.1313$ & & $P=0.0033$ & $\mathrm{~N}=.00508$ & $P * N=0.0088$ & & $P=0.0233$ & $N=0.0356$ & $P * N=0.0616$ \\
\hline \multirow{3}{*}{$\begin{array}{l}\text { Nano } \\
\text { Exp. }\end{array}$} & \multicolumn{11}{|c|}{ Fe additives } \\
\hline & C & $\begin{array}{l}5 \mathrm{mg} \\
\mathrm{kg}^{-1}\end{array}$ & $10 \mathrm{mg} \mathrm{kg}^{-1}$ & Mean & C & $\begin{array}{l}5 \mathrm{mg} \\
\mathrm{kg}^{-1}\end{array}$ & $10 \mathrm{mg} \mathrm{kg}^{-1}$ & Mean & C & $\begin{array}{l}5 \mathrm{mg} \\
\mathrm{kg}^{-1}\end{array}$ & $10 \mathrm{mg} \mathrm{kg}^{-1}$ \\
\hline & $\mathbf{N}$ & & & & $\mathbf{P}$ & & & & $\mathrm{K}$ & & \\
\hline C & 2.783EF & $3.506 \mathrm{~B}$ & $3.146 \mathrm{D}$ & $3.145 A$ & $0.236 \mathrm{C}$ & $0.147 \mathrm{~J}$ & $0.174 \mathrm{H}$ & $0.186 c$ & $1.003 \mathrm{E}$ & $0.630 \mathrm{HIJ}$ & $0.643 \mathrm{HI}$ \\
\hline Zn1 & $1.453 \mathrm{I}$ & $2.900 \mathrm{E}$ & 2.783EF & 2.379D & $0.227 \mathrm{D}$ & $0.142 \mathrm{~J}$ & $0.265 \mathrm{~A}$ & $0.212 A$ & $0.320 \mathrm{M}$ & $2.350 \mathrm{~A}$ & $0.560 \mathrm{IJ}$ \\
\hline $\mathrm{Zn} 2$ & $3.266 \mathrm{CD}$ & $2.660 \mathrm{FG}$ & $2.056 \mathrm{H}$ & $2.661 \mathrm{C}$ & $0.215 E$ & $0.162 \mathrm{I}$ & $0.216 \mathrm{E}$ & $0.197 B$ & $1.673 \mathrm{~B}$ & $0.830 \mathrm{G}$ & $0.666 \mathrm{H}$ \\
\hline Si1 & $2.056 \mathrm{H}$ & $3.866 \mathrm{~A}$ & $0.606 \mathrm{~J}$ & 2.177E & $0.271 \mathrm{~A}$ & $0.188 \mathrm{G}$ & $0.077 \mathrm{~K}$ & $0.178 \mathrm{D}$ & $0.816 G$ & $1.260 \mathrm{D}$ & $0.450 \mathrm{KL}$ \\
\hline Si2 & $2.880 \mathrm{E}$ & $3.266 \mathrm{CD}$ & $2.513 G$ & 2.887B & $0.246 \mathrm{~B}$ & $0.203 \mathrm{~F}$ & $0.190 \mathrm{G}$ & $0.213 A$ & $0.850 F G$ & $0.536 \mathrm{JK}$ & $0.846 \mathrm{FG}$ \\
\hline Mg1 & $2.173 \mathrm{H}$ & $3.386 \mathrm{BC}$ & $2.900 \mathrm{E}$ & $2.820 \mathrm{~B}$ & $0.245 B$ & $0.163 \mid$ & $0.232 \mathrm{CD}$ & $0.213 A$ & $0.990 \mathrm{E}$ & $0.606 \mathrm{HIJ}$ & $0.363 \mathrm{LM}$ \\
\hline Mg2 & $3.993 \mathrm{~A}$ & $2.660 \mathrm{FG}$ & $0.363 \mathrm{~K}$ & 2.338D & $0.142 \mathrm{~J}$ & $0.170 \mathrm{HI}$ & $0.077 \mathrm{~K}$ & $0.129 \mathrm{E}$ & $0.936 \mathrm{EF}$ & $1.526 \mathrm{C}$ & $0.203 \mathrm{~N}$ \\
\hline Mean & $2.658 \mathrm{~B}$ & $3.178 \mathrm{~A}$ & $2.053 \mathrm{C}$ & & $0.226 \mathrm{~A}$ & $0.168 C$ & $0.176 \mathrm{~B}$ & & $0.941 B$ & $1.105 \mathrm{~A}$ & $0.533 \mathrm{C}$ \\
\hline $\begin{array}{l}\text { LSD } \\
\text { at } 5 \%\end{array}$ & $P=0.0632$ & $N=0.0965$ & $P * N=0.1671$ & & $P=0.0032$ & $\mathrm{~N}=0.0049$ & $P * N=0.0086$ & & $P=0.0358$ & $\mathrm{~N}=0.0547$ & $P * N=0.0947$ \\
\hline
\end{tabular}

It was clearly seen that the highest effect in the three trials that were studied in the present work including control, $5 \mathrm{mg} \mathrm{kg}^{-1}$, and $10 \mathrm{mg} \mathrm{kg}{ }^{-1}$ was osculated among Zn2, Mg2, and Si1. The effects of Fe additives with two concentrations of $5 \mathrm{mg} \mathrm{kg}^{-1}$ and $10 \mathrm{mg} \mathrm{kg}^{-1}$ simultaneously with different treatment of NPs on the reduction of available $\mathrm{K}$ are listed in Table 6 . It was clearly seen that the effect of NPs application on the availability of substantial concentrations of $\mathrm{K}$ in soil without any pollutants additives resulted in an osculating in the reduction or increment of the available concentrations of $\mathrm{K}$ in the soil system. The order of sequence for the effects of NPs application on reducing the available concentrations of $\mathrm{K}$ was found to take the following sequence Mg2 > Si2 $>\mathrm{Mg} 1>\mathrm{C}$ (control) $>\mathrm{Zn} 1>\mathrm{Si} 1>\mathrm{Zn} 2$. The highest values affected the reduction of available $\mathrm{K}$ were observed with Mg2, whereas the lowest values were obtained when $\mathrm{Zn} 2$ was added [49,53]. There was a significant difference between all treatments. When Fe was added to the soil as an external pollutant to increase the original exit values by $5 \mathrm{mg} \mathrm{kg}^{-1}$, the effects of NPs application on the availability of $\mathrm{K}$ was found to take the following order $\mathrm{Zn} 2>\mathrm{Si} 2>\mathrm{C}$ (control) $>\mathrm{Mg} 2>$ 
$\mathrm{Zn} 1>\mathrm{Mg} 1>\mathrm{Si}$. The highest value of the effects of adding NPs on the artificially polluted soils with Fe ( $\left.5 \mathrm{mg} \mathrm{kg}^{-1}\right)$ to reduce the availability of $\mathrm{K}$ was found when Zn2 was added to the soil, whereas the lowest effect was found when Si1 was added. There was a significant difference between all treatments except for (Mg1 and Mg2). Increasing the values of an external addition of Fe to $10 \mathrm{mg} \mathrm{kg}^{-1}$ resulted in changing the order of effects of NPs on the availability of $\mathrm{K}$ to the following order $\mathrm{C}$ (control) $>\mathrm{Zn} 2>\mathrm{Mg} 2>\mathrm{Zn} 1>\mathrm{Mg} 1>\mathrm{Si} 2>\mathrm{Si}$. There was a significant difference between all treatments except for (Z1 and Mg1), [53]. It was clearly seen that the highest effects in the three trials that were studied in the present work including control, $5 \mathrm{mg} \mathrm{kg}^{-1}$, and $10 \mathrm{mg} \mathrm{kg}{ }^{-1}$ on $\mathrm{K}_{\text {availability }}$ were osculated among Mg2, Zn2, and control.

\subsubsection{Effect of $\mathrm{Cu}$ additives and NPs treatment on the accumulation of N, P, and $\mathrm{K}$ in the plant}

The effects of $\mathrm{Cu}$ additives with two concentrations of $5 \mathrm{mg} \mathrm{kg}^{-1}$ and $10 \mathrm{mg} \mathrm{kg}^{-1}$ simultaneously with different treatment of NPs on increasing the total amounts of $\mathrm{N}$ in the plant are listed in Table 6. It was clearly seen that the effect of NPs application on increasing the total concentrations of $\mathrm{N}$ without any Cu additives resulted in an osculation in the reduction or increment of $\mathrm{N}$ in the plant,[53]. The order of sequence for the effects of NPs application on the increasing the total $\mathrm{N}$ was found to take the following sequence $\mathrm{Mg} 2>\mathrm{Zn} 2>\mathrm{Si} 2>\mathrm{Si} 1>\mathrm{C}$ (control) $>\mathrm{Zn} 2>\mathrm{Zn} 1>\mathrm{Si}$. The highest values affected the increases of the available $\mathrm{N}$ in the plant were observed with Mg2, whereas the lowest values were obtained when Si1 was added. There was a significant difference between all treatments except for the treatments of (control and Si2) and (Si1 and Mg1). When Cu was added to the soil as an external pollutant to increase the original exit values by $5 \mathrm{mg} \mathrm{kg}^{-1}$, the effects of NPs application on the increment of total $\mathrm{N}$ were found to take the following order Si2 $>\mathrm{C}$ (control) $>$ Mg1 $>$ Zn1 $=$ Mg2 $>$ Zn2 $>$ Si1. The highest value of the effects of adding NPs on the artificially polluted soils with Cu $\left(5 \mathrm{mg} \mathrm{kg}^{-1}\right)$ to increase the total concentrations of $\mathrm{N}$ in the plant was found when $\mathrm{Si} 2$ was added to the soil, whereas the lowest effect was found when Si1 was added,[53]. There was a significant difference between all treatments except for the treatments of (control and Si2) and (Z1 and Mg2). Increasing the values of an external addition of $\mathrm{Cu}$ to $10 \mathrm{mg} \mathrm{kg}^{-1}$ resulted in changing the order of effects of NPs on increase the total concentrations of $\mathrm{N}$ in the plant to the following order Si2 > Si1 > C (control) $>$ Zn2 = Mg1 > Zn1 > Mg2. There was a significant difference between all treatments except for the following treatments (control and Si1) and (Zn1, $\mathrm{Zn} 2$, and Mg1). It was clearly seen that the highest effects in the three trials that were studied in the present work including control, $5 \mathrm{mg} \mathrm{kg}^{-1}$, and $10 \mathrm{mg} \mathrm{kg}^{-1}$ were osculated among Mg2, Si2, and Si2, respectively. The effects of Cu additives with two concentrations of $5 \mathrm{mg} \mathrm{kg}^{-1} \mathrm{and}_{10} \mathrm{mg} \mathrm{kg}{ }^{-1}$ simultaneously with different treatment of NPs on increasing the total amounts of P in the plant are listed in Table 6. It was clearly seen that the effect of NPs application on increasing the total concentrations of $\mathrm{P}$ without any pollutants additives resulted in an osculating in the reduction or increment of $\mathrm{P}$ in the plant. The order of sequence for the effects of NPs application on the increasing the total P was found to take the following sequence Si1 > Si2 > Mg1 > C (control) $>\mathrm{Zn} 1>\mathrm{Zn} 2>$ Mg2. The highest values affected the increases of the available $\mathrm{P}$ were observed with $\mathrm{Si1}$, whereas the lowest values were obtained when Mg2 was added. There was a significant difference between all treatment except for the treatments of ( $\mathrm{Si} 2 \mathrm{and} \mathrm{Mg} 1)$. When Cu was added to the soil as a pollutant to increase the original exit values by $5 \mathrm{mg} \mathrm{kg}^{-1}$, the effects of NPs application on the increment of total P were found to take the following order Zn1 > Si2 >C (control) > $\mathrm{Si} 1>\mathrm{Zn} 2>\mathrm{Mg} 2>\mathrm{Mg} 1$, [53]. The highest value of the effects of adding NPs on the artificially polluted soils with $\mathrm{Cu}\left(5 \mathrm{mg} \mathrm{kg}^{-1}\right)$ to increase the total concentrations of $\mathrm{P}$ in the plant was found when $\mathrm{Zn} 1$ was added to the soil, whereas the lowest effect was found when Mg1 was added. There was a significant difference between all treatments. Increasing the values of an external addition of Cu to $10 \mathrm{mg} \mathrm{kg}^{-1}$ resulted in changing the order of effects of NPs on increase the total concentrations of $\mathrm{P}$ in the plant to the following order Si1 $>\mathrm{Zn} 1>\mathrm{C}$ (control) $>\mathrm{Si} 2>\mathrm{Mg} 1>\mathrm{Mg} 2>\mathrm{Zn} 2$. There was a significant difference between all treatments. It was clearly seen that the highest effects in the three trials that were studied in the present work including the control, 5 mg $\mathrm{kg}^{-1}$, and $10 \mathrm{mg} \mathrm{kg}^{-1}$ were osculated among Si1, Zn1, and Si1, respectively. The effects of Cu additives with two concentrations of $5 \mathrm{mg} \mathrm{kg}{ }^{-1}$ and $10 \mathrm{mg} \mathrm{kg}{ }^{-1}$ simultaneous with different treatments of NPs on increasing the total amounts of K in the plant are listed in Table 6 . It was clearly seen that the effect of NPs applications on increasing the total concentrations of $\mathrm{K}$ without any $\mathrm{Cu}$ additives were resulted in an osculating in the reduction or increment of total $\mathrm{K}$ in the plant. The order of sequence for the effects of NPs application on increasing the total $\mathrm{K}$ was found to take the following sequence $\mathrm{Zn} 2>\mathrm{C}$ (control) $>\mathrm{Mg} 1>$ Mg2 > Si2 > Si1 > Zn1. The highest values affected the increases of the total N were observed with Zn2, whereas the lowest values were obtained when Zn1 was added. There was a significant difference between all treatments. When Cu was added to the soil as an external pollutant to increase the original exit values by $5 \mathrm{mg} \mathrm{kg}^{-1}$, the effects of NPs application on the increment of total K were found to take the following order Si2 $>\mathrm{Zn} 1>\mathrm{Zn} 2>\mathrm{Mg} 2>\mathrm{Si} 1>\mathrm{C}$ (control) $>\mathrm{Mg} 1$. The highest values of the effects of adding NPs on the artificially polluted soils with $\mathrm{Cu}\left(5 \mathrm{mg} \mathrm{kg}^{-1}\right)$ to increase the total concentrations of $\mathrm{K}$ in the plant were found when Si2 was added to the soil, whereas the lowest effect was found when Mg1 was added. There was a significant difference between all treatments except for the treatments of (Z1 and Zn2). Increasing the values of Cu to $10 \mathrm{mg} \mathrm{kg}^{-1}$ resulted in changing the order of effects of NPs on increase the total concentrations of $\mathrm{K}$ in the plant to the following order $\mathrm{C}$ (control) $>\mathrm{Zn} 1>\mathrm{Zn} 2>\mathrm{Si} 2>\mathrm{Mg} 1>\mathrm{Si} 1>\mathrm{Mg} 2[49,53]$. There was a significant difference between all treatments except for the following treatments (control and Zn1). It was clearly seen that the highest effects in the three trials that were studied in the present work including control, $5 \mathrm{mg} \mathrm{kg}^{-1}$, and $10 \mathrm{mg} \mathrm{kg}^{-1}$ were osculated among Zn2, Si2, and control, respectively.

\subsubsection{Effect of Fe additives and NPs treatment on the accumulation of N, P, and $\mathrm{K}$ in the plant}

The effects of Fe additives with two concentrations of $5 \mathrm{mg} \mathrm{kg}^{-1}$ and $10 \mathrm{mg} \mathrm{kg}^{-1}$ simultaneously with different treatment of NPs on increasing the total amounts of $\mathrm{N}$ in the plant are listed in Table 6. It was clearly seen that the effect of NPs application on increasing the total concentrations of $\mathrm{N}$ without any pollutants additives resulted in an osculating in the reduction or increment of $\mathrm{N}$ in the plant. The order of sequence for the effects of NPs application on the increasing the total $\mathrm{N}$ was found to take the following sequence $\mathrm{Mg} 2>\mathrm{Zn} 2>\mathrm{Si} 2>\mathrm{C}$ (control) $>\mathrm{Mg} 1>\mathrm{Si} 1>\mathrm{Zn} 1$. The highest values affected the increases of the total $\mathrm{N}$ were observed with $\mathrm{Mg}$ 2, whereas the lowest values were obtained when $\mathrm{Zn} 1$ was added. There was a significant difference between all treatment except for the treatments of ( $\mathrm{Si} 1$ and $\mathrm{Mg} 1$ ). When Fe was added to the soil as an external addition to increase the original exit values by $5 \mathrm{mg} \mathrm{kg}^{-1}$, the effects of NPs application on the increment of total $\mathrm{N}$ were found to take the following order Si1 $>\mathrm{C}$ (control) $>$ Mg1 $>\mathrm{Si} 1>\mathrm{Zn} 1>\mathrm{Zn} 2=\mathrm{Mg} 2$. The highest value of the effects of adding NPs on the artificially polluted soils with Fe $\left(5 \mathrm{mg} \mathrm{kg}^{-1}\right)$ to increase the total concentrations of $\mathrm{N}$ in the plant was found when Si1 was added to the soil, whereas the lowest effect was found when Mg2 was added. There was a significant difference between all treatments except for the treatments of (Zn2 and Mg2). Increasing the values of polluted Fe to $10 \mathrm{mg} \mathrm{kg}^{-1}$ resulted in changing the order of effects of NPs on increase the total concentrations of $\mathrm{N}$ in

Page $12 / 21$ 
the plant to the following order $\mathrm{C}$ (control) $>\mathrm{Mg} 1>\mathrm{Zn} 1>\mathrm{Si} 2>\mathrm{Zn} 2>\mathrm{Si} 1>\mathrm{Mg} 2$. There was a significant difference between all treatments. It was clearly seen that the highest effects in the three trials that were studied in the present work including control, $5 \mathrm{mg} \mathrm{kg}^{-1}$, and $10 \mathrm{mg} \mathrm{kg}^{-1}$ were osculated among Mg2, Si1, and control, respectively. The effects of Fe additives with two concentrations of $5 \mathrm{mg} \mathrm{kg}^{-1}$ and $10 \mathrm{mg} \mathrm{kg}^{-1}$ simultaneously with different treatment of NPs on increasing the total amounts of $\mathrm{P}$ in the plant are listed in Table 6. It was clearly seen that the effect of NPs application on increasing the total concentrations of $\mathrm{P}$ without any pollutants additives resulted in an osculating in the reduction or increment of $\mathrm{P}$ in the plant[49]. The order of sequence for the effects of NPs application on the increasing the total $\mathrm{P}$ was found to take the following sequence Si1 $>\mathrm{Si} 2>\mathrm{Mg} 1>\mathrm{C}$ (control) $>\mathrm{Zn} 1>\mathrm{Zn} 2>\mathrm{Mg} 2$ which is similar to what was observed with $\mathrm{Cu}$ additives at the same concentrations. The highest values affected the increases of the total P were observed with Si1, whereas the lowest values were obtained when Mg2 was added. There was a significant difference between all treatments except for the treatments of (Si2 and Mg1). When Fe was added to the soil as pollutant to increase the original exit values by $5 \mathrm{mg} \mathrm{kg}^{-1}$, the effects of NPs application on the increment of total P were found to take the following order Si2 $>\mathrm{Si} 1>\mathrm{Mg} 2>\mathrm{Mg} 1>\mathrm{Zn} 2>\mathrm{C}$ (control) $>\mathrm{Si} 1=\mathrm{Mg} 2$. The highest values of the effects of adding NPs on the artificially polluted soils with Fe $\left(5 \mathrm{mg} \mathrm{kg}^{-1}\right)$ to increase the total concentrations of $\mathrm{P}$ in the plant were found when Si2 was added to the soil, whereas the lowest effects were found when Mg2 were added. There was a significant difference between all treatments except for (control and Zn1) and (Zn2 and Mg1). Increasing the values of an external addition of Fe to $10 \mathrm{mg} \mathrm{kg}^{-1}$ resulted in changing the order of effects of NPs on increasing the total concentrations of $P$ in the plant to the following order $\mathrm{Zn} 1>\mathrm{Mg} 1>\mathrm{Zn} 2>\mathrm{Si} 2>\mathrm{C}$ (control) $>\mathrm{Si} 1=\mathrm{Mg} 2$, [53]. There was a significant difference between all treatments. It was clearly seen that the highest effects in the three trials that were studied in the present work including control, $5 \mathrm{mg} \mathrm{kg}^{-1}$, and $10 \mathrm{mg} \mathrm{kg}{ }^{-1}$ were osculated among Si1, Si2, and Zn1, respectively. The effects of Fe additives with two concentrations of $5 \mathrm{mg} \mathrm{kg}^{-1}$ and $10 \mathrm{mg} \mathrm{kg}^{-1}$ simultaneously with different treatment of NPs on increasing the total amounts of $\mathrm{K}$ in the plant are listed in Table 6 . It was clearly seen that the effect of NPs application on increasing the total concentrations of $\mathrm{K}$ without any pollutants additives resulted in an osculating in the reduction or increment of $\mathrm{K}$ in the plant. The order of sequence for the effects of NPs application on increasing the total $\mathrm{K}$ was found to take the following sequence $\mathrm{Zn} 2>\mathrm{C}$ (control) $>\mathrm{Mg} 1>\mathrm{Mg} 2>\mathrm{Si} 2>\mathrm{Si} 1>\mathrm{Zn} 1 \mathrm{which}$ is similar to what was observed during $\mathrm{Cu}$ additives at the same concentrations. The highest values affected the increases of the total $\mathrm{K}$ were observed with $\mathrm{Zn} 2$, whereas the lowest values were obtained when $\mathrm{Zn} 1$ was added. There was a significant difference between all treatments except for (control and Mg1). When Fe was added to the soil as an external addition to increase the original exit values by $5 \mathrm{mg} \mathrm{kg}^{-1}$, the effects of NPs application on the increment of total $\mathrm{K}$ were found to take the following order $\mathrm{Zn} 1 \mathrm{Mg} 2>\mathrm{Si} 1>\mathrm{Zn} 2>\mathrm{C}$ (control) $>\mathrm{Mg} 1>\mathrm{Si}$. The highest value of the effects of adding NPs on the artificially polluted soils with Fe (5

$\mathrm{mg} \mathrm{kg}^{-1}$ ) to increase the total concentrations of $\mathrm{K}$ in the plant was found when $\mathrm{Zn} 1$ was added to the soil, whereas the lowest effect was found when Si2 was added. There was a significant difference between all treatments except for the treatments of (control and Mg1), [49]. Increasing the values of an external addition of Fe to $10 \mathrm{mg} \mathrm{kg}^{-1}$ resulted in changing the order of effects of NPs on increase the total concentrations of $\mathrm{K}$ in the plant to the following order Si2 > $\mathrm{Zn} 2>\mathrm{C}($ control $)>\mathrm{Zn} 1>\mathrm{Si} 1>\mathrm{Mg} 1>\mathrm{Mg}$. There was a significant difference between all treatments. It was clearly seen that the highest effects in the three trials that were studied in the present work including control, $5 \mathrm{mg} \mathrm{kg}^{-1}$, and $10 \mathrm{mg} \mathrm{kg}^{-1}$ were osculated among Zn2, Zn1, and Si2, respectively. The trend of these results agreed with those reported by Ali, etal.,[51]and Hegabet al.,[55, 56].

\subsection{Effect of NPs treatments and Cu and Fe additives on dry and wet weights of Marjoram plant.}

\subsubsection{Effect of NPs treatments and Cu additives on dry and wet weights of Marjoram plant.}

The effects of $\mathrm{Cu}$ additives with different NPs treatments on dry and wet weights of Marjoram are presented in Table 7 . The effects of two concentrations (5 $\mathrm{mg} \mathrm{kg}^{-1}$ and $10 \mathrm{mg} \mathrm{kg}^{-1}$ ) of Cu additives have been investigated. It was clearly seen that the effect of NPs application presented a negative effect on Marjoram dry weight in the experiments that have been carried out without Cu additives. The order of sequence for the effects of NPs application on increasing the dry weight was found to take the following order control $>\mathrm{Si} 2=\mathrm{Mg} 1>\mathrm{Si} 1>\mathrm{Zn} 1>\mathrm{Mg} 2>\mathrm{Zn} 2$. The highest values of means for dry weight were observed in the control treatment, whereas the lowest values were obtained when $\mathrm{Zn} 2$ was added. There was a significant difference between all treatments except for the treatments of (Si2 and Mg2)[53]. When Cu was added to the soil as an external addition to increase the original exit values by $5 \mathrm{mg} \mathrm{kg}{ }^{-1}$, the effects of NPs application on Marjoram dry weight took the following order Zn2 $>$ Mg2 $>$ Si2 $>$ C (control) $>$ Zn1 $>$ Si1 $>$ Mg1. The highest value of the effects of adding NPs on the artificially polluted soils with $\mathrm{Cu}\left(5 \mathrm{mg} \mathrm{kg}^{-1}\right)$ was found when $\mathrm{Zn} 2$ was added to the soil, whereas the lowest effect was found when Mg1 was added. There was a significant difference between all treatments except for the treatments of (control, Zn1, and Si2) and (Si1 and Mg1). Increasing the values of original exist values of Cu by $10 \mathrm{mg} \mathrm{kg}^{-1}$ resulted in changing the order of effects of NPs on Marjoram dry weight to the following order Zn1 > $\mathrm{Zn} 2>\mathrm{Mg} 2>\mathrm{Si} 2>\mathrm{C}$ (control) $>\mathrm{Si} 1 \mathrm{Mg}$. There was a significant difference between all treatments except for the treatments of (control, Si1, Si2 and Mg1) and (Zn2, Mg2). It was clearly seen that the highest effect in the three trials that were studied in the present work including control, 5 mg kg ${ }^{-1}$, and 10 mg kg-1 was relevant to the additives of control, Zn2, and Zn1, respectively. It was clearly seen that the effect of NPs application presented a negative effect on Marjoram wet weight in the experiments that have been carried out without $\mathrm{Cu}$ additives. The order of sequence for the effects of NPs application on increasing the wet weight was found to take the following order control $>\mathrm{Si} 2=\mathrm{Mg} 1>\mathrm{Si} 1>\mathrm{Mg} 2>\mathrm{Zn} 1>\mathrm{Zn} 2$. The highest values of means for wet weight were observed in the control treatment, whereas the lowest values were obtained when $\mathrm{Zn} 2$ was added which is similar to data that has been observed in dry weight. There was a significant difference between all treatments except for the treatments of Si2 and Mg1. When Cu was added to the soil as an external pollutant to increase the original exiting values by $5 \mathrm{mg} \mathrm{kg}^{-1}$, the effects of NPs application on Marjoram wet weight took the following order Zn2 $>\mathrm{Si} 1=\mathrm{Mg} 2>\mathrm{Zn} 1=\mathrm{Mg} 1>\mathrm{C}$ (control) $>\mathrm{Si} 2$. The highest value of the effects of adding NPs on the artificially polluted soils with $\mathrm{Cu}\left(5 \mathrm{mg} \mathrm{kg}^{-1}\right)$ was found when $\mathrm{Zn} 2$ was added to the soil, whereas the lowest effect was found when Si2 was added. There was a significant difference between all treatments except for the treatments of control, Zn1, Si1, $\mathrm{Mg} 1$, and Mg2. Increasing the values of original exist values of $\mathrm{Cu}$ addition by $10 \mathrm{mg} \mathrm{kg}^{-1}$ resulted in changing the order of effects of NPs on Marjoram wet weight to the following order $\mathrm{Zn} 1>\mathrm{Zn} 2>\mathrm{C}($ control $)>\mathrm{Mg} 1>\mathrm{Si} 2=\mathrm{Mg} 2>\mathrm{Si} 1$. There was a significant difference between all treatments except for the

Page 13/21 
treatments of (control and $\mathrm{Zn} 2)$ and (Si2, Mg1, and Mg2). It was clearly seen that the highest effects in the three trials that were studied in the present work including control, $5 \mathrm{mg} \mathrm{kg}^{-1}$, and $10 \mathrm{mg} \mathrm{kg}^{-1}$ were relevant to the additives of control, Zn2, and Zn1, respectively similar to what was observed in dry weight. The fresh and dry weights were affected by the use of Zn, Si, Mg NPs and may be the lower biomass in the control plants might be due to the higher Fe and $\mathrm{Cu}$ levels in these plants. These elements mediated reduction in plant growth might be associated with the disturbance of several mechanisms in plants such as chlorophyll biosynthesis, water deficit, and ultra structural alteration in plant [57]. These results are in close conformity with Venkatachalam et al.,[58].

Table 7

Effect of NPs treatments and pollutants additives on dry and wet weights of Marjoram plant.

\begin{tabular}{|c|c|c|c|c|c|c|c|c|}
\hline \multicolumn{9}{|l|}{ Cu additives } \\
\hline NPs & C & $5 \mathrm{mg} \mathrm{kg}^{-1}$ & $10 \mathrm{mg} \mathrm{kg}^{-1}$ & Mean & C & $5 \mathrm{mg} \mathrm{kg}^{-1}$ & $10 \mathrm{mg} \mathrm{kg}^{-1}$ & Mean \\
\hline \multicolumn{9}{|l|}{ Treatments } \\
\hline \multicolumn{3}{|c|}{ Dry weight } & \multicolumn{6}{|c|}{ Wet weight } \\
\hline C & $36.96 \mathrm{~A}$ & 15.30DEF & 14.96DEF & $22.41 \mathrm{~A}$ & $51.66 \mathrm{~A}$ & 25.33DEF & 25.66DEF & $34.22 \mathrm{~A}$ \\
\hline Zn1 & 17.96CDE & 14.30DEF & $18.96 \mathrm{CD}$ & 17.07BC & 22.66EF & 25.66DEF & $36.66 \mathrm{~B}$ & 28.33B \\
\hline $\mathrm{Zn} 2$ & $11.96 \mathrm{~F}$ & 17.96CDE & 16.96CDE & $15.63 \mathrm{C}$ & $20.33 \mathrm{~F}$ & $32.66 \mathrm{BC}$ & 26.66DEF & 26.55B \\
\hline Si1 & $20.96 \mathrm{BC}$ & 13.63EF & 14.30DEF & 16.41BC & $30.66 \mathrm{BCD}$ & 26.00DEF & $20.66 \mathrm{~F}$ & 25.77B \\
\hline $\mathrm{Si} 2$ & $23.96 \mathrm{~B}$ & 15.96DEF & 15.63DEF & 18.52B & $32.66 \mathrm{BC}$ & 22.00EF & 22.66EF & 25.77B \\
\hline Mg1 & $23.96 \mathrm{~B}$ & 13.63EF & 14.30DEF & 17.30BC & $32.66 \mathrm{BC}$ & 25.66DEF & 23.33EF & 27.22B \\
\hline Mg2 & 17.96CDE & 17.30CDE & 16.96CDE & 17.41BC & $27.66 \mathrm{CD}$ & 26.00DEF & 22.66EF & 25.44B \\
\hline Mean & $21.96 \mathrm{~A}$ & 15.49B & 16.01B & & $31.19 \mathrm{~A}$ & 26.19B & 25.47B & \\
\hline LSD at $5 \%$ & $P=1.82$ & $N=2.78$ & $P * N=4.83$ & & $P=2.41$ & $N=3.68$ & $P * N=6.38$ & \\
\hline \multicolumn{9}{|l|}{ Fe additives } \\
\hline \multirow[t]{2}{*}{$\begin{array}{l}\text { NPs } \\
\text { Treatments }\end{array}$} & C & $5 \mathrm{mg} \mathrm{kg}^{-1}$ & $10 \mathrm{mg} \mathrm{kg}^{-1}$ & Mean & C & $\begin{array}{l}5 \mathrm{mg} \\
\mathrm{kg}^{-1}\end{array}$ & $\begin{array}{l}10 \mathrm{mg} \\
\mathrm{kg}^{-1}\end{array}$ & Mean \\
\hline & \multicolumn{4}{|l|}{ Dry weight } & \multicolumn{2}{|c|}{ Wet weight } & & \\
\hline C & $36.96 \mathrm{~B}$ & 19.96EF & 19.96EF & $25.63 B$ & 51.66B & $32.66 \mathrm{EF}$ & $38.66 \mathrm{D}$ & 41.00B \\
\hline Zn1 & $17.96 \mathrm{FG}$ & $16.96 \mathrm{G}$ & $16.96 \mathrm{G}$ & 17.30D & $22.66 \mathrm{IJ}$ & $22.66 \mathrm{IJ}$ & $26.00 \mathrm{HI}$ & 23.77E \\
\hline Zn2 & $11.96 \mathrm{H}$ & 19.96EF & 19.96EF & 17.30D & $20.33 \mathrm{~J}$ & $32.66 \mathrm{EF}$ & $32.66 \mathrm{EF}$ & 28.55D \\
\hline Si1 & 20.96DE & $22.96 \mathrm{CD}$ & $15.30 \mathrm{G}$ & $19.74 \mathrm{C}$ & $30.66 \mathrm{FG}$ & 35.66DE & $22.00 \mathrm{IJ}$ & 29.44D \\
\hline $\mathrm{Si} 2$ & $23.96 \mathrm{C}$ & $15.63 G$ & $34.96 \mathrm{~B}$ & 24.85B & $32.66 \mathrm{EF}$ & $28.00 \mathrm{GH}$ & $52.66 \mathrm{~B}$ & $37.77 \mathrm{C}$ \\
\hline Mg1 & $23.96 \mathrm{C}$ & $23.96 \mathrm{C}$ & $65.96 \mathrm{~A}$ & $37.96 \mathrm{~A}$ & $32.66 \mathrm{EF}$ & $43.66 \mathrm{C}$ & $94.66 \mathrm{~A}$ & $57.00 \mathrm{~A}$ \\
\hline Mg2 & $17.96 \mathrm{G}$ & $15.96 \mathrm{G}$ & 19.96EF & 17.96D & $27.66 \mathrm{GH}$ & $21.66 \mathrm{~J}$ & $32.66 \mathrm{EF}$ & 27.33D \\
\hline Mean & 21.96B & $19.34 \mathrm{C}$ & $27.58 \mathrm{~A}$ & & 31.19B & $31.00 \mathrm{~B}$ & 42.76A & \\
\hline LSD at $5 \%$ & $P=1.09$ & $\mathrm{~N}=1.67$ & $P * N=2.90$ & & $P=1.62$ & $\mathrm{~N}=2.48$ & $P * N=4.29$ & \\
\hline
\end{tabular}

\subsubsection{Effect of NPs treatments and Fe additives on dry and wet weights of Marjoram plant.}

The effects of Fe additives with different NPs treatments on dry and wet weights of Marjoram are presented in Table 7. The effects of two concentrations of 5 $\mathrm{mg} \mathrm{kg}^{-1}$ and $10 \mathrm{mg} \mathrm{kg}^{-1}$ of Feon dry and wet weights of Marjoram plant have been investigated. It was clearly seen that the effect of NPs application presented a negative effect on Marjoram dry weight in the experiments that have been carried out without Fe additives. The order of sequence for the effects of NPs application was found to take the following order $\mathrm{C}$ (control) $>\mathrm{Si} 2=\mathrm{Mg} 1>\mathrm{Si} 1>\mathrm{Zn} 1>\mathrm{Mg} 2>\mathrm{Zn} 2$. The highest values of means for dry weight were observed in the control treatment, whereas the lowest values were obtained when $\mathrm{Zn} 2$ was added. There was a significant difference between all treatments except for the treatments of $\mathrm{Si} 2$ and Mg1. When Fe was added to the soil as an external addition to increase the original exit values by $5 \mathrm{mg} \mathrm{kg}^{-1}$, the effects of NPs application on Marjoram dry weight took the following order Mg1 > Si1 > C (control) = Zn2 > Zn1 > Mg2 > Si2. The highest value of the effects of adding NPs on the artificially polluted soils with Fe $\left(5 \mathrm{mg} \mathrm{kg}^{-1}\right)$ was found when Mg1 was added to the soil, whereas the lowest effect was found when Si2 was added. There was a significant difference between all treatments except for the treatments of (control and Zn2) and (Zn1, Si2, and Mg2)[49, 53]. Increasing the values of original exist values of Fe by $10 \mathrm{mg} \mathrm{kg}^{-1}$ resulted in changing the order of effects of NPs on Marjoram dry weight to the following 
order Mg1 > Si2 > C (control) $=\mathrm{Zn} 2=\mathrm{Mg} 2>\mathrm{Zn} 1>\mathrm{Si} 1$. There was a significant difference between all treatment except for the treatments of (control, Zn2, and $\mathrm{Mg} 2)$ and (Zn1 and Si1). It was clearly seen that the highest effects in the three trials that were studied in the present work including control, 5 mg kg ${ }^{-1}$, and 10 $\mathrm{mg} \mathrm{kg}^{-1}$ were relevant to the additives of control, $\mathrm{Mg} 1$, and $\mathrm{Mg} 1$, respectively. It was clearly seen that the effect of NPs application presented a negative effect on Marjoram wet weight in the experiments that have been carried out without Fe additives. The order of sequence for the effects of NPs application was found to take the following order $\mathrm{C}$ (control) $>\mathrm{Si} 2=\mathrm{Mg} 1>\mathrm{Si} 1>\mathrm{Mg} 2>\mathrm{Zn} 1>\mathrm{Zn} 2$. The highest values of means for wet weight were observed in the control treatment, whereas the lowest values were obtained when $\mathrm{Zn} 2$ was added. There was a significant difference between all treatments except for the treatments of (Si2 and Mg1). When Fe was added to the soil as an external addition to increase the original exit values by $5 \mathrm{mg} \mathrm{kg}^{-1}$, the effects of NPs application on Marjoram wet weight took the following order Mg1 > Si1 > control $=\mathrm{Zn} 2>\mathrm{Si} 2>\mathrm{Zn} 1>\mathrm{Mg} 2$. The highest values of the effects of adding NPs on the artificially polluted soils with Fe $\left(5 \mathrm{mg} \mathrm{kg}^{-1}\right)$ were found when $\mathrm{Mg} 1$ was added to the soil, whereas the lowest effect was found when Mg2 was added. There was a significant difference between all treatments except for the treatments of control and $\mathrm{Zn} 2$. Increasing the values of original exist values of Fe by $10 \mathrm{mg} \mathrm{kg}{ }^{-1}$ resulted in changing the order of effects of NPs on Marjoram wet weight to the following order Mg1 $>$ Si2 $>$ C (control) $>$ Zn2 $>$ Mg2 $>$ Zn1 $>$ Si1. There was a significant difference between all treatment except for the treatments of ( $\mathrm{Zn} 2$ and Mg2). It was clearly seen that the highest effect in the three trials that were studied in the present work including control, $5 \mathrm{mg} \mathrm{kg}^{-1}$, and $10 \mathrm{mg} \mathrm{kg}^{-1}$ was relevant to the additives of control, Mg1, and Si2, respectively. These results are in close conformity with Tripathiet al.,[59] who reported that Supply of SiO2 NPs enhanced the photosynthetic pigments in Cr-stressed pea leaves

\section{Conclusion}

In the present study, we have carried out the green synthesis of different nanoparticles to investigate its effect on the quality of irrigation water, the availability of some heavy metals in soil and plant, and the productivity of Marjoram. In general, the term of nanotechnology has emerged recently in several fields of interest that refers to the research and innovation that is concerned with making materials on a very small size close to the scale of atoms and molecules. The results obtained from our experiments explored that the addition of nanoparticles (NPs) materials have resulted in noticeable variations in the removal percentages of both $\mathrm{Cu}$ and $\mathrm{Fe}$. The maximum values obtained for adsorption of $\mathrm{Cu}$ on $\mathrm{ZnO}, \mathrm{MgO}$, and $\mathrm{SiO}_{2} \mathrm{NPs}$, within $\mathrm{pH}(3-5)$ were $89.9 \%$, 83.3\%, and $68.36 \%$ for respectively. Whereas, the maximum adsorption values of $\mathrm{Fe}$ at $\mathrm{pH} 3.3$ were $82 \%, 80 \%$, and $65 \%$ for $\mathrm{ZnO}, \mathrm{MgO}$, and $\mathrm{SiO} \mathrm{NPs}_{2}$, respectively. It was clearly seen that the effect of NPs application on the availability of substantial concentrations of Cu without any pollutants additives resulted in the reduction of the available $\mathrm{Cu}$ in the soil samples, and that same tendency was observed with the substantial concentrations of Fe exist in the soil. Adding NPs to the soil system had positive effects on Cu uptake via the plant. The effect of NPs and the addition of Cu and Fe on the availability of NPK in the soil system were very completed and osculated from one treatment to another. The same tendency was observed with the total concentration of NPK in the plant. It was clearly seen that the effects of NPs application have presented a negative effects on Marjoram dry and wet weight in the experiments that have been carried out without the additions of either $\mathrm{Cu}$ or Fe.

\section{Declarations}

\section{Acknowledgment}

The present work was funded by Desert Research Center Research No. 520CT2020.

\section{References}

1. Tom, "Nanotechnology for sustainable water treatment-A review," Mater. Today Proc., 2021.

2. Azonano, "scholar." p. https://www.azonano.com/article.aspx?ArticlelD=113, 2021, [Online]. Available: https://www.azonano.com/article.aspx? ArticlelD $=1134$.

3. Gomez, L.Narayan, X.Zhao, R. A. Jia, M. L. Bernal, J. R. Lopez-Moreno, Peralta-Videa,"Effects of nano-enabled agricultural strategies on food quality: Current knowledge and future research needs". Journal of Hazardous Materials, 401, 2021, 123385.

4. Awwad, N. M. Salem, A. O. Abdeen, "Biosynthesis of Silver Nanoparticles using Olea europaea Leaves Extract and its Antibacterial Activity", Nanoscience and Nanotechnology, Vol. 2, No.6, 2012, pp. 164-170.

5. Hudlikar, S. Joglekar, M. Dhaygude, K. Kodam,“Latex-mediated synthesis of ZnS nanoparticles”, Journal of Nanoparticle Research, Vol.14 2012 , pp. 865

6. Singhal, R. Bhavesh, K. Kasariya, A. R. Sharma, R. P. Singh, "Biosynthesis of silver nanoparticles using Ocimum sanctum (Tulsi) leaf extract and screening its antimicrobial activity", Journal of Nanoparticle Research, Vol. 13, 2011, pp.2981-2988.

7. Alagumuthu , R.Kirubha, "Green synthesis of silver nanoparticles using Cissus quadrangularis plant extract and their antibacterial activity University", International Journal of Nanomaterials and Biostructures, Vol. 2, No. 3, 2012,pp. 30-33

8. Mason, S. Vivekanandhan, M. Misra, A. K. Mohanty, "Switchgrass (Panicum virgatum) Extract Mediated Green Synthesis of Silver Nanoparticles”, World Journal of Nano Science and Engineering, Vol. 2, 2012,pp.47-52

9. Liu and R. Lal, "Potentials of engineered nanoparticles as fertilizers for increasing agronomic productions," Sci. Total Environ., vol. 514, 2015, pp. 131139.

10. M. M. A. Aziz, M. N. A. Hasaneen, and A. M. Omer, "Nano chitosan-NPK fertilizer enhances the growth and productivity of wheat plants grown in sandy soil," Spanish J. Agric. Res., vol. 14, no. 1, 2016, p. 17.

11. Adisa, V. L. R. Pullagurala, J. R. Peralta-Videa, C. O. Dimkpa, W. H. Elmer, J. L. Gardea-Torresdey, J. C. White,"Recent advances in nano-enabled fertilizers and pesticides: a critical review of mechanisms of action". Environmental Science: Nano, 6(7) (2019) 2002-2030. 
12. Chhipa, "Nanofertilizers and nanopesticides for agriculture," Environ. Chem. Lett., vol. 15, no. 1, 2017, pp. 15-22.

13. Abou-Shady ,H. El-Araby, "Electro-agric, a novel environmental engineering perspective to overcome the global water crisis via marginal water reuse," Nat. Hazards Res., no. July, 2021, doi: 10.1016/j.nhres.2021.10.004.

14. Faria, J. A. Oliveira, B. S Baeza, L.de Miera, M. A. Calvo, L.Gilarranz, L.Naval, "Sewage treatment using Aqueous Phase Reforming for reuse purpose". Journal of Water Process Engineering, 37, 2020, 101413.

15. Ricart , A. M. Rico, "Assessing technical and social driving factors of water reuse in agriculture: A review on risks, regulation and the yuck factor," Agric. Water Manag., vol. 217, 2019, pp. 426-439.

16. López-Morales , L. Rodríguez-Tapia, “On the economic analysis of wastewater treatment and reuse for designing strategies for water sustainability: Lessons from the Mexico Valley Basin," Resour. Conserv. Recycl., vol. 140, 2019, pp. 1-12.

17. Inglese, G. Sortino, Citrus History, Taxonomy, Breeding, and Fruit Quality, Oxford Research Encyclopedia of Environmental Science, 2019.

18. Guimarães, L. Barros, J. C. M. Barreira, M. J. Sousa, A. M. Carvalho, I. C. F. R. Ferreira, "Targeting excessive free radicals with peels and juices of citrus fruits: Grapefruit, lemon, lime and orange," Food Chem. Toxicol., vol. 48, no. 1, pp. 99-106, 2010, doi: https://doi.org/10.1016/j.fct.2009.09.022.

19. A. Jawameer, R. H. Peshawa, H. Mahmood, “Characterization of Antioxidant Property and Chemical Composition of Lemon (Citrus lemon L.) Peel Extracts," 2017.

20. Abou-Shady, "Recycling of polluted wastewater for agriculture purpose using electrodialysis: Perspective for large scale application," Chem. Eng. J., vol. 323, pp. 1-18, 2017.

21. Abou-Shady, "Reclaiming salt-affected soils using electro-remediation technology: PCPSS evaluation," Electrochim. Acta, vol. 190, pp. 511-520, 2016, doi: https://doi.org/10.1016/j.electacta.2016.01.036.

22. Cottenie, M. Verlso, L. Kilkens, G. Velghe and R. Camerlynck, “Chemical Analysis of Plants and Soils”. Lab. Agroch. State Univ. Gent, 1982, Belgium

23. C.Dhank ,G.V. Johnson,"Testing soils for available nitrogen. In: Soil testing and plant analysis”. 3rd ed., SSSA Book Series No.3, Westerman RL (Ed.). Madison, WI: Soil Sci. Soc. of Am. J.;1990, 127-139.

24. Soltanpour, P.N. (1985) Use of AB-DTPA Soil Test to Evaluate Element Availability and Toxicity. Communication in Soil Science and Plant Analysis, 16, 323-338.

http://dx.doi.org/10.1080/00103628509367607

25. H. letswaart, J. H. letswaart, J.H.,. A taxonomic revision of the genus Origanum (Labiatae) (Vol. 4, p. 158). The Hague: Leiden University Press, 1980.

26. Turek, K. Wieczorek, W. M. Wolf, “Digestion Procedure and Determination of Heavy Metals in Sewage Sludge-An Analytical Problem," Sustainability , vol. 11, no. 6. 2019, doi: 10.3390/su11061753.

27. Dobrucka, "Synthesis of MgO Nanoparticles Using Artemisia abrotanum Herba Extract and Their Antioxidant and Photocatalytic Properties," Iran. J. Sci. Technol. Trans. A Sci., vol. 42, no. 2, pp. 547-555, 2018, doi: 10.1007/s40995-016-0076-x.

28. N. A. Uda, S. C. Gopinath, U. Hashim, N. H. Halim, N. A. Parmin, M. N. Uda, P. Anbu,“Production and characterization of silica nanoparticles from fly ash: conversion of agro-waste into resource". Preparative biochemistry \& biotechnology, 51(1) 2021, 86-95.

29. Jaiswal, M. Samant, A. Kadir, K. Chaturvedi, A. B. Nawale, V. L. Mathe, P. M. Dongre,“UV radiation protection by thermal plasma synthesized zinc oxide nanosheets". Journal of Inorganic and Organometallic Polymers and Materials, 27(5)2017, 1211-1219.

30. Suresh, P. C. Nethravathi, Udayabhanu, H. Rajanaika, H. Nagabhushana, S. C. Sharma, "Green synthesis of multifunctional zinc oxide (ZnO) nanoparticles using Cassia fistula plant extract and their photodegradative, antioxidant and antibacterial activities," Mater. Sci. Semicond. Process., vol. 31, pp. 446454, 2015, doi: https://doi.org/10.1016/j.mssp.2014.12.023.

31. Habibah, M. H. Wahid, L. N. Ismail, R. A. Bakar, M. D. Rozana, M. M.Rusop,"Improvement in dielectric properties of bilayer ZnO/MgO films deposited by Sol-Gel technique". In RSM 2013 IEEE Regional Symposium on Micro and Nanoelectronics,2013,(pp. 285-288) IEEE.

32. Suresh, V.Pradheesh, M.Alexramani, S. I. Sundrarajan, Hong, "Green synthesis and characterization of hexagonal shaped MgO nanoparticles using insulin plant (Costus pictus D. Don) leave extract and its antimicrobial as well as anticancer activity," Adv. Powder Technol., vol. 29, no. 7, pp. 1685-1694, 2018, doi: https://doi.org/10.1016/j.apt.2018.04.003.

33. Suresh,V.Pradheesh, M.Alexramani, S. I. Sundrarajan, Hong, "Green synthesis and characterization of zinc oxide nanoparticle using insulin plant ( Costus pictus D. Don ) and investigation of its antimicrobial as well as anticancer activities," Adv. Nat. Sci. Nanosci. Nanotechnol., vol. 9, no. 1, p. 15008, 2018, doi: 10.1088/2043-6254/aaa6f1.

34. Zheng, C. Chen, Y. Zhan, X. Lin, Q. Zheng, K. Wei, Y. Zhu, "Luminescence and photocatalytic activity of ZnO nanocrystals: correlation between structure and property". Inorganic chemistry, 46(16)2007, 6675-6682.

35. H. Kotp, "Enhancement of industrial effluents quality by using nanocomposite Mg/Al LDH ultrafiltration membranes". Journal of Inorganic and Organometallic Polymers and Materials, 30, 2020, 5244-5260.

36. H. Kotp, "High-flux TFN nanofiltration membranes incorporated with Camphor-Al203 nanoparticles for brackish water desalination”. Chemosphere, 265, 2021, 128999.

37. Pirhashemi , A. Habibi-Yangjeh, "Ultrasonic-assisted preparation of novel ternary ZnO/Ag3V04/Ag2CrO4 nanocomposites and their enhanced visible-light activities in degradation of different pollutants," Solid State Sci., vol. 55, pp. 58-68, 2016, doi: https://doi.org/10.1016/j.solidstatesciences.2016.02.006.

38. Azam, A. S. Ahmed, M. Oves, M. S. Khan, S. S. Habib, A. Memic, "Antimicrobial activity of metal oxide nanoparticles against Gram-positive and Gramnegative bacteria: a comparative study," Int. J. Nanomedicine, vol. 7, 2012, p. 6003.

39. Hernandez , A. C. Pierre, "Influence of the sol- gel acidic synthesis conditions on the porous texture and acidity of $\mathrm{SiO} 2-\mathrm{Al} 2 \mathrm{O} 3$ catalysts with a low Al proportion," Langmuir, vol. 16, no. 2, 2000, pp. 530-536.

Page $16 / 21$ 
40. Moncada, R. Quijada, J. Retuert, "Nanoparticles prepared by the sol-gel method and their use in the formation of nanocomposites with polypropylene," Nanotechnology, vol. 18, no. 33, p. 335606, 2007.

41. Bayramoğlu , M. Y. Arıca, "Construction a hybrid biosorbent using Scenedesmus quadricauda and Ca-alginate for biosorption of Cu (II), Zn (II) and Ni (II): kinetics and equilibrium studies," Bioresour. Technol., vol. 100, no. 1, pp. 186-193, 2009.

42. Yang, "Statistical mechanical study on the Freundlich isotherm equation," J. Colloid Interface Sci., vol. 208, no. 2, pp. 379-387, 1998.

43. -Q. Jiang, C. Cooper, S. Ouki, “Comparison of modified montmorillonite adsorbents: part I: preparation, characterization and phenol adsorption,” Chemosphere, vol. 47, no. 7, pp. 711-716, 2002.

44. Taha, K. Ahmad, A. A. Aziz, Z. Chik, "Geoenvironmental aspects of tropical residual soils," in tropical residual soils engineering, CRC Press, 2004, pp. 391420.

45. Boparai, M. Joseph, D. M. O'Carroll, "Kinetics and thermodynamics of cadmium ion removal by adsorption onto nano zerovalent iron particles," J. Hazard. Mater., vol. 186, no. 1, 2011, pp. 458-465.

46. An, B. Y. Park, D. S. Kim, “Crab shell for the removal of heavy metals from aqueous solution," Water Res., vol. 35, no. 15, 2001, pp. 3551-3556.

47. B. Singh, D. C. Rupainwar, G. Prasad, K. C. Jayaprakas, “Studies on the Cd (II) removal from water by adsorption,” J. Hazard. Mater., vol. 60, no. 1,1998, pp. 29-40.

48. Araújo, A. C. M. Castro, A. Fiúza, "The use of nanoparticles in soil and water remediation processes". Materials Today: Proceedings, 2(1), 2015, 315-320.

49. Baragaño, R. Forján., R. Welte, L., J. L. R. Gallego, "Nanoremediation of As and metals polluted soils by means of graphene oxide nanoparticles". Scientific reports, 10(1), 2020, 110-囚

50. H.Saifulah, A.Naeem, Z.Rengel, S.Dahlawi,"Timing of foliar Zn application plays a vital role in minimizing cd accumulation in wheat". Environ Sci Pollut Res., 2016, 223:16432-16439.

51. Hussain,S,Ali, M. Rizwan, M.Z. Rehman, M.R.Javed, M.Imran, S.A.Chatha, R.Nazir,"Zinc oxide nanoparticles alter the wheat physiological response and reduce the cadmium uptake by plants". Environ Pollut., 2018, 242:1518-1526.

52. Wang,C.Xu, Z.C.Luo, H.H.Zhu, S.Wang, Q.H.Zhu, D.Y.Huang, Y.Z.Zhang, J.Xiong, Y.B.He,"Foliar application of Zn can reduce cd concentrations in rice (Oryza sativa L.) under field conditions”. Environ Sci Pollut Res.,2018, 25:29287-29294.

53. Ali, M. Rizwan, S. Noureen, S. Anwar, B. Ali, M. Naveed, P. Ahmad, "Combined use of biochar and zinc oxide nanoparticle foliar spray improved the plant growth and decreased the cadmium accumulation in rice (Oryza sativa L.) plant". Environmental Science and PollutionResearch, 26(11), 2019, 1128811299.

54. C.Pandey,“Phytoremediation of heavy metals from fly ash pond by Azolla caroliniana”. Ecotoxicol Environ Saf, 2012, 82:8-12.

55. H. Hagab, Y. H. Kotp, D. Eissa, "Using nanotechnology for enhancing phosphorus fertilizer use efficiency of peanut bean grown in sandy soils". Journal of Advanced Pharmacy Education \& Research| Jul-Sep, 8(3), 2018, 59-67.

56. H.Hegab, W.F. Abou Batta, M. M.El-Shazly, “Effect of Mineral, Nano and Bio Nitrogen Fertilization on Nitrogen Content and Productivity of Salvia Officnalis Plant”. J.Soil Sci. and Agric. Eng., Mansoura Univ., Vol. 9(9): 2018, 393 - 401.

57. Ali, Q.Tao, Y,Zhou, R.A.Gill, S.Ali, M.T. Rafiq, L.Xu, W. Zhou,"Aminolevolinic acid mitigates the cadmium-induced changes in Brassica napus as revealed by the biochemical and ultra-structural evaluation of roots". Ecotoxicol Environ Saf , 2013, 92:271-280.

58. Venkatachalam, M.Jayaraj, R.Manikandan, N.Geetha, E.R.Rene, N.C.Sharma, S.V.Sahi,"Zinc oxide nanoparticles (ZnONPs) alleviate heavy metal-induced toxicity in Leucaena leucocephala seedlings: a physiochemical analysis. Plant Physiol Biochem, 2017,110: 59-69.

59. K. Tripathi, V. P. Singh, S. M. Prasad, D. K. Chauhan, N. K. Dubey, "Silicon nanoparticles (SiNp) alleviate chromium (VI) phytotoxicity in Pisum sativum (L.) seedlings", Plant Physiology and Biochemistry 96, 2015.

\section{Figures}




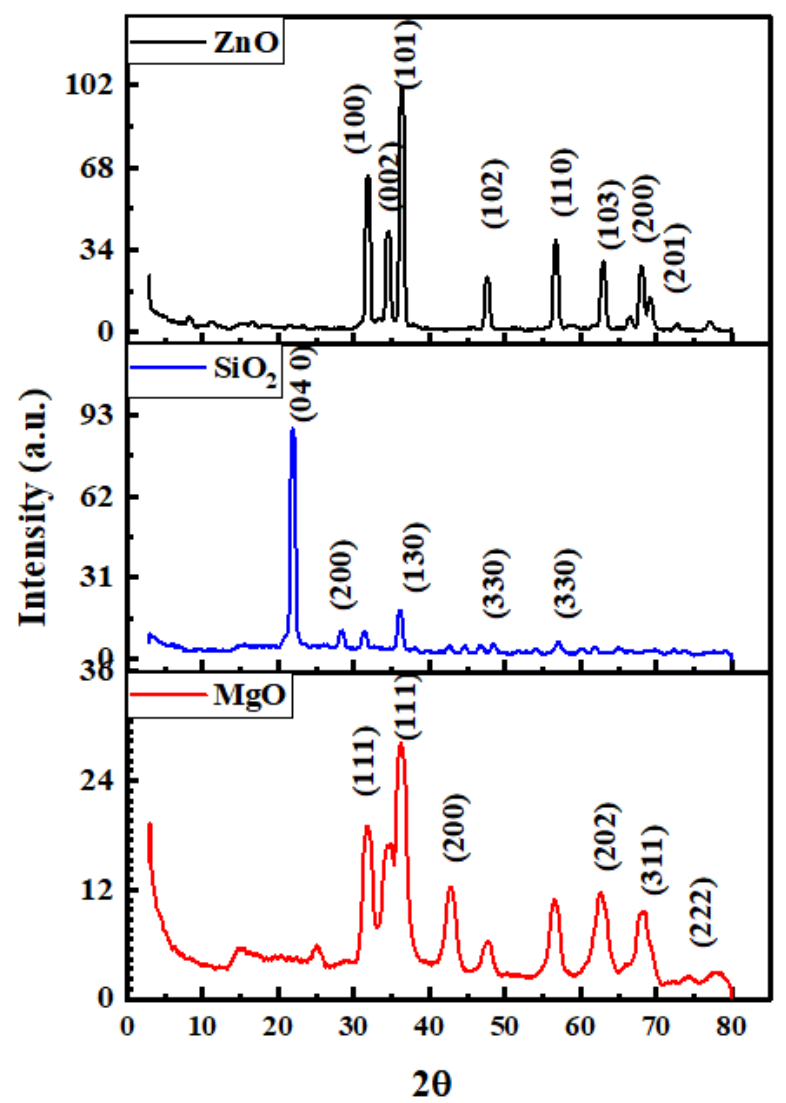

Figure 1

The X-ray diffraction profile of NPs synthesized using the lemon peel extract. 


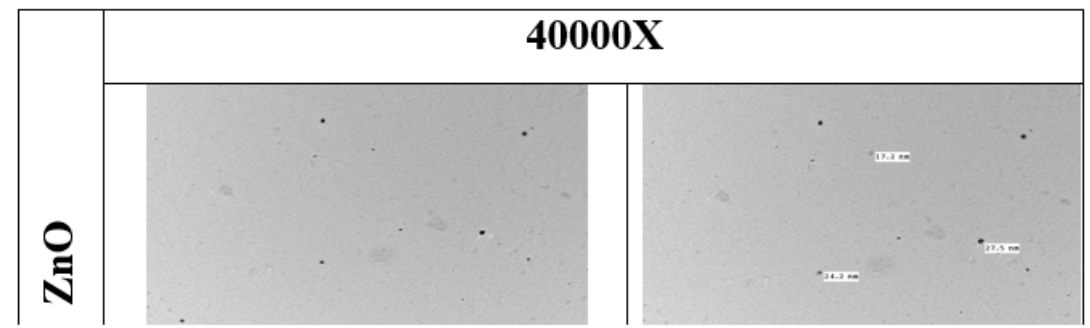

Figure 2

The TEM micrograph of $\mathrm{MgO}, \mathrm{SiO}_{2}$, and $\mathrm{ZnO}$ nanoparticles synthesized by lemon peel extract. 


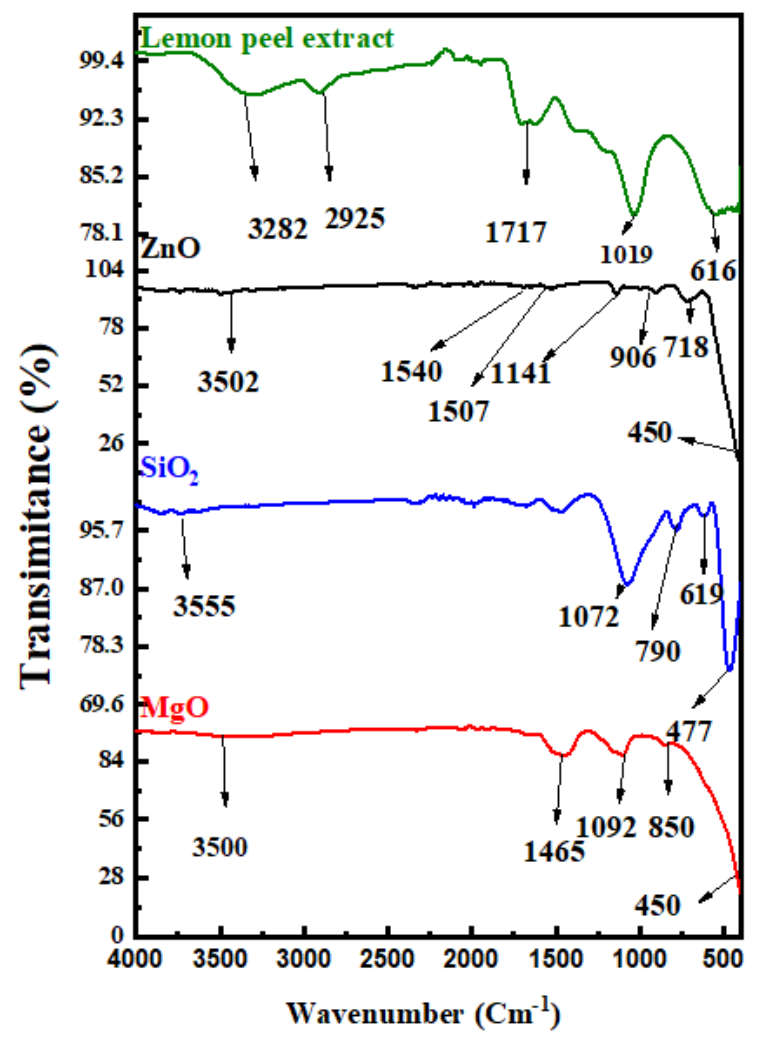

Figure 3

The FTIR spectra of the $\mathrm{MgO}, \mathrm{SiO}_{2}$, and $\mathrm{ZnO}$ nanoparticles and lemon peel extract.

(b)
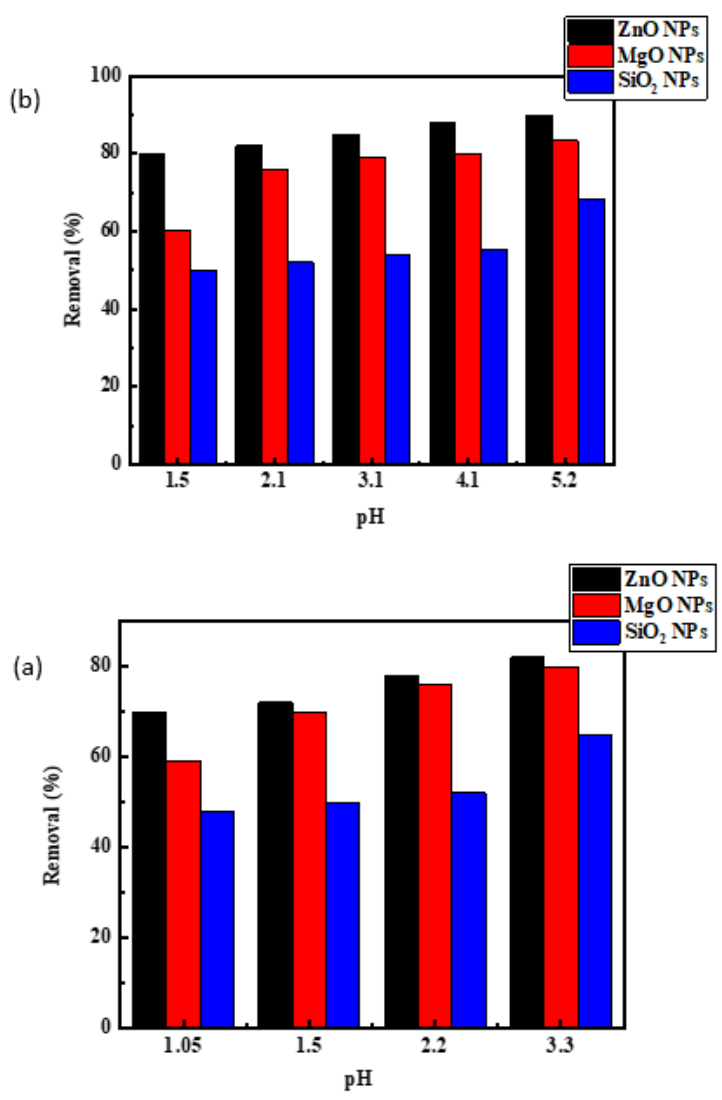

Figure 4

Effect of $\mathrm{pH}$ on adsorption of $\mathrm{Cu}(\mathrm{a})$ and Fe (b) ions (conditions: $10 \mathrm{~g} \mathrm{l}^{-1}$ adsorbent, $10 \mathrm{ml}$ of $50 \mathrm{mg} \mathrm{L}^{-1}$ of ions, duration of oscillation time of $24 \mathrm{~h}$ at temperature $\left.25^{\circ} \mathrm{C}\right)$. 


(1.5)

\section{Figure 5}

Linearized Freundlich isotherms for $\mathrm{Cu}^{2+}$ and $\mathrm{Fe}^{3+}$ ions adsorption on $\mathrm{ZnO}, \mathrm{MgO}$, and $\mathrm{SiO}_{2} \mathrm{NPs}$ at different temperatures.

\section{Figure 6}

Linearized Langmuir isotherms for $\mathrm{Cu}$ and $\mathrm{Fe}$ ions adsorption on $\mathrm{ZnO}, \mathrm{MgO}$, and $\mathrm{SiO}_{2} \mathrm{NPs}$ at different temperatures. 